\title{
The effects of morphology, mobility size, and secondary organic aerosol (SOA) material coating on the ice nucleation activity of black carbon in the cirrus regime
}

\author{
Cuiqi Zhang ${ }^{1,2}$, Yue Zhang ${ }^{3,4,5, a}$, Martin J. Wolf ${ }^{2, b}$, Leonid Nichman ${ }^{6}$, Chuanyang Shen ${ }^{2,7}$, Timothy B. Onasch ${ }^{4,5}$, \\ Longfei Chen ${ }^{1}$, and Daniel J. Cziczo ${ }^{2,8,9}$ \\ ${ }^{1}$ School of Energy and Power Engineering, Beihang University, Beijing, China \\ ${ }^{2}$ Department of Earth, Atmospheric, and Planetary Sciences, Massachusetts Institute of Technology, \\ Cambridge, MA, 02139, USA \\ ${ }^{3}$ Department of Environmental Sciences and Engineering, University of North Carolina at Chapel Hill, Chapel Hill, \\ NC, 27599, USA \\ ${ }^{4}$ Aerodyne Research Incorporated, Billerica, MA, 01821, USA \\ ${ }^{5}$ Department of Chemistry, Boston College, Chestnut Hill, MA, 02467, USA \\ ${ }^{6}$ Flight Research Laboratory, National Research Council Canada, Ottawa, ON, K1V 9B4, Canada \\ ${ }^{7}$ Department of Atmospheric and Oceanic Sciences, School of Physics, Peking University, Beijing, China \\ ${ }^{8}$ Department of Civil and Environmental Engineering, Massachusetts Institute of Technology, Cambridge, \\ MA, 02139, USA \\ ${ }^{9}$ Department of Earth, Atmospheric, and Planetary Sciences, Purdue University, West Lafayette, IN, 47907, USA \\ ${ }^{a}$ now at: Department of Atmospheric Sciences, Texas A\&M University, College Station, 77843, TX, USA \\ b now at: Yale Center for Environmental Law and Policy, Yale Law School and Yale School of the Environment, \\ New Haven, CT, 06511, USA
}

Correspondence: Longfei Chen (chenlongfei@buaa.edu.cn)

Received: 3 August 2020 - Discussion started: 2 September 2020

Revised: 30 October 2020 - Accepted: 12 November 2020 - Published: 19 November 2020

\begin{abstract}
There is evidence that black carbon (BC) particles may affect cirrus formation and, hence, global climate by acting as potential ice nucleating particles (INPs) in the troposphere. Nevertheless, the ice nucleation (IN) ability of bare BC and BC coated with secondary organic aerosol (SOA) material remains uncertain. We have systematically examined the IN ability of $100-400 \mathrm{~nm}$ size-selected BC particles with different morphologies and different SOA coatings representative of anthropogenic (toluene and $n$-dodecane) and biogenic ( $\beta$-caryophyllene) sources in the cirrus regime $\left(-46\right.$ to $\left.-38^{\circ} \mathrm{C}\right)$. Several $\mathrm{BC}$ proxies were selected to represent different particle morphologies and oxidation levels. Atmospheric aging was further replicated with the exposure of SOA-coated $\mathrm{BC}$ to $\mathrm{OH}$. The results demonstrate that the $400 \mathrm{~nm}$ hydrophobic BC types nucleate ice only at or near the homogeneous freezing threshold. Ice formation at cir-
\end{abstract}

rus temperatures below homogeneous freezing thresholds, as opposed to purely homogeneous freezing, was observed to occur for some BC types between 100 and $200 \mathrm{~nm}$ within the investigated temperature range. More fractal BC particles did not consistently act as superior INPs over more spherical ones. SOA coating generated by oxidizing $\beta$-caryophyllene with $\mathrm{O}_{3}$ did not seem to affect BC IN ability, probably due to an SOA-phase state transition. However, SOA coatings generated from $\mathrm{OH}$ oxidation of various organic species did exhibit higher IN-onset supersaturation ratio with respect to ice $\left(\mathrm{SS}_{i}\right)$, compared with bare $\mathrm{BC}$ particles, with the tolueneSOA coating showing an increase in $\mathrm{SS}_{i}$ of $0.1-0.15$ while still below the homogeneous freezing threshold. Slightly oxidized toluene SOA coating seemed to have a stronger deactivation effect on BC IN ability than highly oxidized toluene SOA, which might be caused by oligomer formation and the 
phase state transition of toluene SOA under different oxidation levels. $n$-dodecane and $\beta$-caryophyllene-derived SOAcoated $\mathrm{BC}$ only froze in the homogeneous regime. We attribute the inhibition of IN ability to the filling of the pores on the BC surface by the SOA material coating. OH exposure levels of $n$-dodecane and $\beta$-caryophyllene SOA coating experiments, from an equivalent atmospheric exposure time from 10 to $90 \mathrm{~d}$, did not render significant differences in the IN potential. Our study of selected BC types and sizes suggests that increases in diameter, compactness, and/or surface oxidation of $\mathrm{BC}$ particles lead to more efficient IN via the pore condensation freezing (PCF) pathway, and that coatings of common SOA materials can inhibit the formation of ice.

\section{Introduction}

Cirrus clouds affect the global energy balance predominantly by more effectively trapping long-wave terrestrial radiation than reflecting solar energy (e.g., Kärcher et al., 2007; Heymsfield et al., 2017; Kärcher, 2018). In cirrus clouds, ice crystals can form via two pathways, i.e., homogeneous and heterogeneous ice nucleation (IN; Pruppacher and Klett, 2010). Homogeneous freezing is the spontaneous freezing of solution droplets without any foreign surfaces aiding the process (Pruppacher and Klett, 2010). Heterogeneous IN occurs more readily than homogeneous IN due to the presence of an ice nucleating particle (INP) at a lower supersaturation with respect to ice $\left(\mathrm{SS}_{i}\right)$ or warmer temperature (DeMott et al., 2003; Vali et al., 2015; Kanji et al., 2017). Deposition IN is one classical heterogeneous IN mode in which solid ice is formed by direct water vapor deposition onto an INP surface. Recently, laboratory studies demonstrated that ice formation at thermodynamic conditions relevant to classical deposition IN on porous material at cirrus temperature (below $-38^{\circ} \mathrm{C}$ ) might actually be initiated by the homogeneous freezing of liquid water held within the cavities below water saturation due to the inverse Kelvin effect (Marcolli, 2014; David et al., $2019,2020)$. This pathway by which porous material might form ice below water saturation below $-38^{\circ} \mathrm{C}$ is referred to as pore condensation and freezing (PCF; Marcolli, 2014).

Black carbon (BC) particles from aircraft emissions may be an important direct source of anthropogenic INPs in the tropopause (Petzold et al., 1998; Seinfeld, 1998; Popovicheva et al., 2004; Burkhardt and Kärcher, 2011; Kärcher, 2018). Global mass-based aviation BC emission rates are estimated to range between 2 and $20 \mathrm{Gg} \mathrm{yr}^{-1}$ (Bond et al., 2004; Lee et al., 2010; Bond et al., 2013; X. Zhang et al., 2019), while the number-based aviation BC emission rate is estimated to be equivalent to $\sim 1.3 \%$ of total ground anthropogenic BC emissions (X. Zhang et al., 2019). Aviation fuel usage is projected to increase twofold to fourfold in the next few decades (Lee et al., 2009, 2010), simultaneously increasing aircraft-induced cloudiness (Petzold et al.,
1998; Seinfeld, 1998; Popovicheva et al., 2004; Burkhardt and Kärcher, 2011; Kärcher, 2018). However, the role of $\mathrm{BC}$ aerosol-cloud-climate interactions in cirrus formation remains highly uncertain (IPCC, 2013).

Laboratory experiments have been carried out to study the effects of isolated processes on BC IN ability in detail. Both well-characterized, commercially available BC (e.g., DeMott et al., 1999; Fornea et al., 2009; Brooks et al., 2014; Mahrt et al., 2018; Nichman et al., 2019) and soot particles from combustion sources (e.g., Diehl and Mitra, 1998; Möhler et al., 2005b; Dymarska et al., 2006; Kanji and Abbatt, 2006; Koehler et al., 2009; Crawford et al., 2011; Friedman et al., 2011; Kanji et al., 2011; Kulkarni et al., 2016; Mahrt et al., 2018; Nichman et al., 2019) have been used to investigate the IN ability of BC particles, with a particular focus on IN below $-38^{\circ} \mathrm{C}$. According to previous studies (e.g., Koehler et al., 2009; Friedman et al., 2011; Kulkarni et al., 2016; Mahrt et al., 2018; Nichman et al., 2019), the following physicochemical properties of particles may play vital roles in determining BC IN activity: (a) mobility diameter $\left(d_{\mathrm{m}}\right)$, (b) morphology, (c) surface oxidation state, and (d) organic material coating. It is widely acknowledged that larger particles act as more efficient INPs (e.g., Pruppacher and Klett, 2010), which has also been confirmed by recent heterogeneous IN experiments with various INPs (e.g., Welti et al., 2009; Lüönd et al., 2010; Marcolli, 2014; Mason et al., 2016; Mahrt et al., 2018; Nichman et al., 2019). Although the mechanism remains uncertain, one common theory is that the IN ability and rate are positively correlated to particle surface active sites density (Fletcher, 1960, 1969), an empirical parameter that is relevant to particle size (e.g., Connolly et al., 2009; Kiselev et al., 2017). Similarly, the probability of a BC aggregate to contain a pore with the right properties (e.g., pore size and surface hydrophilicity) increases with increasing aggregate diameter, which would favor PCF for larger particles (Mahrt et al., 2018). The IN ability of monodisperse BC particles with the size range of 100-800 $\mathrm{nm}$ has previously been characterized (Koehler et al., 2009; Friedman et al., 2011; Kulkarni et al., 2016; Mahrt et al., 2018; Nichman et al., 2019). The lower size limit at which BC particles act as active INPs below $-38^{\circ} \mathrm{C}$ varied between 100 and $400 \mathrm{~nm}$. However, the size threshold below which BC cannot nucleate ice at thermodynamic conditions relevant to the classical deposition mode at cirrus temperature and the underlying mechanism is still uncertain.

Laboratory experiments and field observations confirmed that $\mathrm{BC}$ morphology and surface chemistry may change significantly during atmospheric aging, leading to changes in particle surface area, shape, and chemical composition (e.g., Slowik et al., 2007; Khalizov et al., 2009; Tritscher et al., 2011; Fu et al., 2012; China et al., 2015b; Li et al., 2016; Moffet et al., 2016; Li et al., 2017; Wang et al., 2017; Bhandari et al., 2019). Commonly used BC morphology characteristics are those derived from 2-D projected electron microscopy images, including fractal dimension $\left(D_{\mathrm{f}}\right)$, round- 
ness, aspect ratio (AR), and convexity (e.g., Ramachandran and Reist, 1995; Lee and Kramer, 2004; China et al., 2013, 2014, 2015b; Kulkarni et al., 2016). Effective density and surface area have also been utilized to reflect the BC morphology and mixing state (Tritscher et al., 2011; Kulkarni et al., 2016; Mahrt et al., 2018; Nichman et al., 2019).

Freshly emitted BC particles are typically hydrophobic, fractal, nanoscale $(<200 \mathrm{~nm})$ aggregates with branched or chain-like structures (e.g., Kinsey et al., 2010; Beyersdorf et al., 2014; Liati et al., 2014; Vander Wal et al., 2014; Lobo et al., 2015; Moore et al., 2017). BC aggregate surface area is determined by the primary particle sizes, the number of primary particles, and the way primary particles are connected (Kittelson, 1998). Nichman et al. (2019) reported a generally positive correlation between $\mathrm{BC}$ particle surface area and IN activity for particles with the same size. For smaller particles, Mahrt et al. (2018) presented a complex dependence of BC IN activity on particle size, surface area, and BC surface hydrophilicity. They attributed BC IN activity to the PCF mechanism (Marcolli, 2014; David et al., 2019, 2020) in which the IN of $\mathrm{BC}$ is considered as being the homogeneous freezing of liquid water taken up in mesopores $(2-50 \mathrm{~nm})$ due to the capillary effect (Fisher et al., 1981).

The surface chemistry of the emitted particles is governed by the source and the host environment in which the particles evolve. Nascent BC particles can interact with volatile species, such as sulfates and unburned hydrocarbons in the aircraft cooling exhaust plumes, and grow (e.g., Lefebvre, 1998; Onasch et al., 2009; Anderson et al., 2011; Kärcher, 2018). These particles can remain suspended in the atmosphere for days to weeks (Cape et al., 2012; Lund et al., 2018), or even months in the tropopause (Pusechel et al., 1992; Yu et al., 2019), during which the exposure to atmospheric biogenic and anthropogenic emissions and oxidation can lead to complex secondary organic aerosol (SOA) coatings (Jacobson, 2001; Zhang et al., 2008; China et al., 2015b; Kulkarni et al., 2016; Zhang et al., 2018b). Numerous experiments have been conducted to investigate the effects of surface coating on the BC IN ability. Hygroscopic BC particles (Koehler et al., 2009), or BC particles coated by hygroscopic materials such as sulfuric acid (DeMott et al., 1999; Möhler et al., 2005b; Crawford et al., 2011) and water-soluble organic acids (Friedman et al., 2011; Nichman et al., 2019) and SOA (Kulkarni et al., 2016), tended to enhance the BC water uptake ability and form aqueous solutions on the BC surface, moving the IN-onset $\mathrm{SS}_{i}$ towards the homogeneous freezing threshold. Hydrophobic organic coatings tended to impede the surface interaction between $\mathrm{BC}$ and water molecules. Möhler et al. (2005b), Crawford et al. (2011), and Mahrt et al. (2018) reported a transition from the heterogeneous to homogeneous freezing mode for combusted $\mathrm{BC}$ with an increasing organic carbon (OC) content. Ozone (Friedman et al., 2011) and hydroxyl (OH) radical (Chou et al., 2013; Kulkarni et al., 2016) oxidation can change surface functional groups of $\mathrm{BC}$ particles and enhance hydrophilicity, but no distinguishable BC IN activity change has been observed. Despite these previous efforts, the influence of particle morphology, chemistry, and aging, as well as the microphysical mechanism behind BC IN ability, remains ambiguous.

In this work, we examine the effects of the particle mobility diameter, morphology, and SOA coating on the IN ability of several aerosolized BC proxies as a function of $\mathrm{SS}_{i}$ in a cirrus-relevant temperature regime (from -46 to $-38^{\circ} \mathrm{C}$ ). Representative species of anthropogenic (toluene and $n$-dodecane) and biogenic ( $\beta$-caryophyllene) volatile organic compounds (VOCs) were chosen to simulate the potential photochemical atmospheric aging processes of BC. Different aging durations in equivalent atmospheric times were simulated by controlling the $\mathrm{OH}$ radical exposure. Our results help to clarify the effects of physicochemical properties and SOA formation on BC IN ability and on cirrus formation in the upper troposphere.

\section{Experiment: materials and methods}

\subsection{Materials}

\subsubsection{SOA coating materials}

Three organic species, namely toluene, $n$-dodecane, and $\beta$ caryophyllene, were selected to represent atmospheric SOA precursors from anthropogenic and biogenic sources (Table B1 in Appendix B). Toluene and $n$-dodecane are often selected as surrogate jet fuel components to investigate combustion and emission characteristics because they have been proven well suited to representing the tens of hundreds of components found in mainstream jet fuels (e.g., Dooley et al., 2010, 2012; Zhang et al., 2016; Zhao et al., 2017). Field aircraft emission studies also confirm the presence of these unburned aliphatic and aromatic organic compounds in the particles of aircraft engine exhaust fumes (e.g., Pison and Menut, 2004; Kinsey et al., 2011; Beyersdorf et al., 2012; Timko et al., 2014). These organic compounds may coat $\mathrm{BC}$ particles, forming $\mathrm{BC}$-containing aerosols in the engine plume. Moreover, toluene is considered a dominant aromatic SOA precursor due to anthropogenic activities (e.g., Pandis et al., 1992), and it serves as a proxy for other light aromatic species (such as xylenes, alkylbenzenes, naphthalene, etc.) in atmospheric aromatic-seeded SOA formation models (e.g., Hildebrandt Ruiz et al., 2015). $n$-dodecane is one of the most studied long-chain aliphatic SOA precursors (e.g., Presto et al., 2010; Yee et al., 2013; Loza et al., 2014), representing less volatile aliphatic species. Modeling and field studies suggest that less volatile organic species might be significant anthropogenic SOA precursors in highly populated areas (Hodzic et al., 2010; Tsimpidi et al., 2010; LeeTaylor et al., 2011; Hodzic et al., 2016), among which $n$ dodecane has relatively higher emission rate (Lee-Taylor et al., 2011). Terpenes are biogenic organics emitted by plants, 
among which $\beta$-caryophyllene has been found to be one of the most atmospherically abundant sesquiterpenes originating from agricultural plants and pine trees and other sources (Arey et al., 1991; Ciccioli et al., 1999; Helmig et al., 2006; Sakulyanontvittaya et al., 2008; Guenther et al., 2012; Henrot et al., 2017). Even though the atmospheric abundance of $\beta$ caryophyllene is not as significant as other biogenic organics, such as isoprene and $\alpha$-pinene, its high reactivity towards $\mathrm{O}_{3}$ and $\mathrm{OH}$ radicals to form oxidized products with low volatility makes $\beta$-caryophyllene an appreciable biogenic SOA source in the atmosphere (Shu and Atkinson, 1995; Calogirou et al., 1997; Hoffmann et al., 1997; Griffin et al., 1999; Helmig et al., 2006; Lee et al., 2006; Jaoui et al., 2007). An up to $7 \mathrm{ng} \mathrm{m}^{-3}$ atmospheric concentration of $\beta$-caryophyllene tracers during the summertime was reported (Jaoui et al., 2007).

\subsubsection{Black carbon samples}

Three types of commercially available BC particles (Raven 2500 Ultra, hereafter R2500U; Birla Carbon USA, Inc.; REGAL 330R, hereafter R330R; Cabot Corporation; CAB-OJET 300, hereafter COJ300; Cabot Corporation Inkjet Colorants and Inks Division), corresponding to different surface chemistry and morphology regimes, were studied as proxies of atmospheric BC. Table 1 summarizes the characteristics of these BC proxies. R2500U and R330R are carbonaceous black pigment powders generated by incomplete combustion (Joyce and Henry, 2006; Cabot Corporation, 2020). COJ300 is a highly dispersible ink due to the 4-carboxyphenyl-modified surface (Johnson and Belmont, 1999). COJ300 is selected for its high degree of oxidation, which is confirmed by the particle analysis by laser mass spectrometry (PALMS) chemical analysis (see Fig. A1 in Appendix A), classifying it as the most oxidized BC proxy in this study. R2500U and R330R are unoxidized but differ in morphology, which was confirmed by morphology characterization and PALMS analysis (see Sect. 3.1). R2500U, $\mathrm{R} 330 \mathrm{R}$, and COJ300 were chosen as proxies of freshly emitted BC, atmospheric-compacted BC, and atmosphericoxidized BC, respectively. IN properties of $800 \mathrm{~nm}$ R330R and R2500U particles were previously studied (Nichman et al., 2019). This work addresses the remaining questions raised in the previous study and focuses on the impact of particle size, morphology, and surface oxidation.

\subsection{BC particle generation and characterization}

\subsubsection{BC particle generation}

Figure 1 shows a schematic diagram of the experimental apparatus used in this study. The particle-generation setup is enclosed in the gray dashed box. Suspensions of R2500U and R330R and a diluted COJ300 dispersion (dilution ratio $1: 30$ ) were atomized with a three jet collision nebu- lizer (CH Technologies (USA), Inc), and bare BC experiments are marked by blue lines in Fig. 1. Suspensions of BC powder (R2500U and R330R) were prepared by mixing $1 \mathrm{~g} \mathrm{BC}$ powder with $100 \mathrm{~mL}$ deionized (DI) water. The mixture was then sonicated for $10 \mathrm{~min}$ to make the suspension more uniform. The flow rates through the nebulizer were 1.5 standard liters per minute (SLPM) and 2.2 SLPM for bare $\mathrm{BC}$ experiments and $\mathrm{BC}-\mathrm{SOA}$ mixing experiments, respectively, which were controlled by a mass flow controller (MFC; model MC-2SLPM-D; Alicat Scientific). The atomized $\mathrm{BC}$ particles were dried by passing them through two consecutive $43 \mathrm{~cm}$ silica gel diffusion dryers (DDU 570/H; Topas $\mathrm{GmbH}$ ). All samples were then neutralized and size selected. For bare BC experiments, a Brechtel Manufacturing Inc (BMI) differential mobility analyzer (DMA; model 2002; Brechtel Manufacturing Inc) was used to size-select particles, with a $500 \mathrm{~nm}$ cut-off size impactor installed at the DMA inlet to remove large particles. For BC SOA mixing experiments, a TSI DMA (model 3081; TSI Incorporated) was utilized to select $350 \mathrm{~nm}$ COJ300 particles with no impactor applied. The sheath-to-sample ratios for bare BC and BC SOA mixing experiments were, respectively, $\sim 6: 1$ and $4: 1$. Compared with the widely used sheath-to-sample ratio (10:1; Karlsson and Martinsson, 2003), the lower ratios in our experiments might broaden the BC particle size distribution, yet still offer a satisfactory number concentration at the target particle size (Fig. 2) because of the large particle size being selected (Karlsson and Martinsson, 2003). The relative humidity $(\mathrm{RH})$ of the aerosol stream entering the DMA measured by the BMI built-in RH sensor was $\sim 16 \%$. During the bare BC IN experiments, the size-resolved particle number concentration was monitored with a BMI condensation particle counter (BMI CPC; model 1700; Brechtel Manufacturing Inc).

\subsubsection{Characterization of $\mathrm{BC}$ morphology}

The 200, 300, and $400 \mathrm{~nm}$ R2500U and $400 \mathrm{~nm} \mathrm{R} 330 \mathrm{R}$ and COJ300 BC particles were collected on 300 mesh carbon film copper grids (Ted Pella, Inc) with a microorifice uniform deposit impactor (MOUDI; model M135-10; TSI Incorporated) for offline morphology analysis. The flow rate through the impactor was controlled by a mass flow controller (MFC; model MC-5SLPM-D; Alicat Scientific) at 2 SLPM so that the cut-off size of the impactor was $100 \mathrm{~nm}$. The samples were analyzed offline in a Zeiss Merlin high-resolution scanning electron microscope (HRSEM; Carl Zeiss Microscopy $\mathrm{GmbH})$.

Table 1 summarizes the morphological characteristics, including the projected area-equivalent diameter $\left(d_{\mathrm{a}}\right)$, aspect ratio (AR), roundness, circularity, and 3-D fractal dimension $\left(D_{\mathrm{f}}\right)$, for different BC types and sizes derived from HRSEM images $(\times 30000$ to $\times 150000)$. The primary particle diameter $\left(\overline{d_{\mathrm{pp}}}\right)$ is the geometric average of the length and width of a clear primary particle (see Figs. A3 and A4 and the 
Table 1. Characteristics of selected BC proxies in this study. $a_{\mathrm{BET}-\mathrm{N}_{2}}$ is the BET specific surface area based on $\mathrm{N}_{2}$ adsorption isotherms, $d_{\mathrm{m}}$ is the particle mobility diameter, and $\overline{d_{\mathrm{a}}}$ denotes the mean 2-D projected area-equivalent aggregate diameter derived from scanning electron microscope (SEM) images. Mean aspect ratio $(\overline{\mathrm{AR}})$, roundness ( $\overline{\text { Roundness}})$, and circularity (Circularity) are the geometric mean morphology parameters derived from several aggregates and are defined in Sect. 2.2.2. $\overline{d_{\mathrm{pp}}}$ denotes the mean geometric diameter of primary particles measured from SEM images, and $N$ is the number of primary particles analyzed for each BC type and size. $D_{\mathrm{f}}$ denotes the 3 -D fractal dimension derived from 2-D SEM images, and $d_{\mathrm{va}}$ is the particle vacuum aerodynamic diameter measured by the particle analysis by laser mass spectrometry (PALMS). Values in parentheses are the corresponding 1 standard deviation, and values in square brackets are the $95 \%$ confidence intervals of $D_{\mathrm{f}}$.

\begin{tabular}{|c|c|c|c|c|c|}
\hline BC type & & $\mathrm{R} 2500 \mathrm{U}$ & & COJ300 & R330R \\
\hline Composition & & Furnace black & & $\begin{array}{r}\text { (4-carboxyphenyl)-modified } \\
\text { carbon black }^{\mathrm{a}}\end{array}$ & Furnace black \\
\hline Chemical abstracts service (CAS) no. & & $1333-86-4$ & & $1106787-35-2$ & $1333-86-4$ \\
\hline Specific gravity $\left(20^{\circ} \mathrm{C}\right)$ & & $1.7-1.9^{\mathrm{a}}$ & & 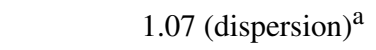 & $1.7-1.9^{\mathrm{a}}$ \\
\hline Bulk density $\left(\mathrm{g} \mathrm{cm}^{-3}\right)$ & & $20-380$ & & - & $20-380$ \\
\hline $\mathrm{pH}$ & & $7.0^{\mathrm{b}} ; 4-11^{\mathrm{c}}$ & & $7.0-8.6^{\mathrm{a}}$ & $6.9^{\mathrm{b}} ; 2-11^{\mathrm{c}}$ \\
\hline Solubility & & Insoluble & & Insoluble but dispersible & Insoluble \\
\hline$a_{\mathrm{BET}^{-\mathrm{N}_{2}}}\left(\mathrm{~m}^{2} \mathrm{~g}^{-1}\right)^{\mathrm{a}, \mathrm{d}}$ & & 270 & & 200 & 90 \\
\hline$d_{\mathrm{m}}(\mathrm{nm})$ & 200 & 300 & 400 & 400 & 400 \\
\hline$\overline{d_{\mathrm{a}}}(\mathrm{nm})( \pm 1 \sigma)$ & $\begin{array}{r}316.9 \\
(109.3)\end{array}$ & $\begin{array}{l}403.5 \\
(82.5)\end{array}$ & $\begin{array}{r}343.5 \\
(106.3)\end{array}$ & $\begin{array}{r}629.4 \\
(308.3)\end{array}$ & $\begin{array}{r}816.6 \\
(355.3)\end{array}$ \\
\hline$\overline{\mathrm{AR}}( \pm 1 \sigma)$ & $\begin{array}{r}1.22 \\
(0.16)\end{array}$ & $\begin{array}{r}1.36 \\
(0.27)\end{array}$ & $\begin{array}{r}1.44 \\
(0.29)\end{array}$ & $\begin{array}{r}1.19 \\
(0.17)\end{array}$ & $\begin{array}{r}1.33 \\
(0.28)\end{array}$ \\
\hline$\overline{\text { Roundness }}( \pm 1 \sigma)$ & $\begin{array}{r}0.81 \\
(0.06)\end{array}$ & $\begin{array}{r}0.77 \\
(0.08)\end{array}$ & $\begin{array}{r}0.73 \\
(0.09)\end{array}$ & $\begin{array}{r}0.84 \\
(0.08)\end{array}$ & $\begin{array}{r}0.75 \\
(0.10)\end{array}$ \\
\hline$\overline{\text { Circularity }}( \pm 1 \sigma)$ & $\begin{array}{r}0.78 \\
(0.18)\end{array}$ & $\begin{array}{r}0.64 \\
(0.14)\end{array}$ & $\begin{array}{r}0.61 \\
(0.15)\end{array}$ & $\begin{array}{r}0.72 \\
(0.20)\end{array}$ & $\begin{array}{r}0.53 \\
(0.16)\end{array}$ \\
\hline$\overline{d_{\mathrm{pp}}}(\mathrm{nm})( \pm 1 \sigma)$ & $\begin{array}{r}41.9 \\
(12.4)\end{array}$ & $\begin{array}{l}35.5 \\
(9.9)\end{array}$ & $\begin{array}{r}34.5 \\
(11.4)\end{array}$ & $\begin{array}{l}34.2 \\
(9.9)\end{array}$ & $\begin{array}{r}45.4 \\
(13.6)\end{array}$ \\
\hline$N$ & 242 & 256 & 343 & 139 & 251 \\
\hline$D_{\mathrm{f}}[95 \%$ confidence interval $]$ & $\begin{array}{r}2.02 \\
{[1.85,2.18]}\end{array}$ & $\begin{array}{r}1.92 \\
{[1.30,2.53]}\end{array}$ & $\begin{array}{r}1.92 \\
{[1.68,2.16]}\end{array}$ & $\begin{array}{r}2.34 \\
{[2.12,2.56]}\end{array}$ & $\begin{array}{r}2.31 \\
{[2.01,2.61]}\end{array}$ \\
\hline Median $d_{\mathrm{va}} \mathrm{e}$ & - & - & 608.7 & 610.6 & - \\
\hline Effective density $\left(\mathrm{g} \mathrm{cm}^{-3}\right)^{\mathrm{f}}$ & - & - & 1.52 & 1.44 & - \\
\hline $\begin{array}{l}\text { Spectra percentage exhibiting } \\
m / z=16 \text { signal }\end{array}$ & - & - & 2.8 & 21.0 & - \\
\hline Mean $\mathrm{O}: \mathrm{C}$ ratio $^{\mathrm{g}}( \pm 1 \sigma)$ & - & - & $\begin{array}{r}0.008 \\
(0.024)\end{array}$ & $\begin{array}{r}0.024 \\
(0.036)\end{array}$ & - \\
\hline
\end{tabular}

\footnotetext{
${ }^{a}$ Information offered by the manufacturer's data sheet. ${ }^{\mathrm{b}}$ Measured by Nichman et al. (2019), using a VWR International pH meter. ${ }^{\mathrm{c}}$ Measured by the manufacturer in compliance with ASTM D1512. ${ }^{\mathrm{d}}$ BET specific surface area measured by the manufacturer, using $\mathrm{N}_{2}$ adsorption in compliance with ASTM D4820. ${ }^{\mathrm{e}}$ Converted from the measured time of flight. ${ }^{\mathrm{f}}$ Calculated by dividing median $d_{\mathrm{va}}$ by $d_{\mathrm{m}}\left(400 \mathrm{~nm}\right.$ in this study) and multiplying with the reference density $1 \mathrm{~g} \mathrm{~cm}{ }^{-3}$ (Cziczo et al., 2006$)$.

$\mathrm{g}$ Calculated from the PALMS spectra area.
} 


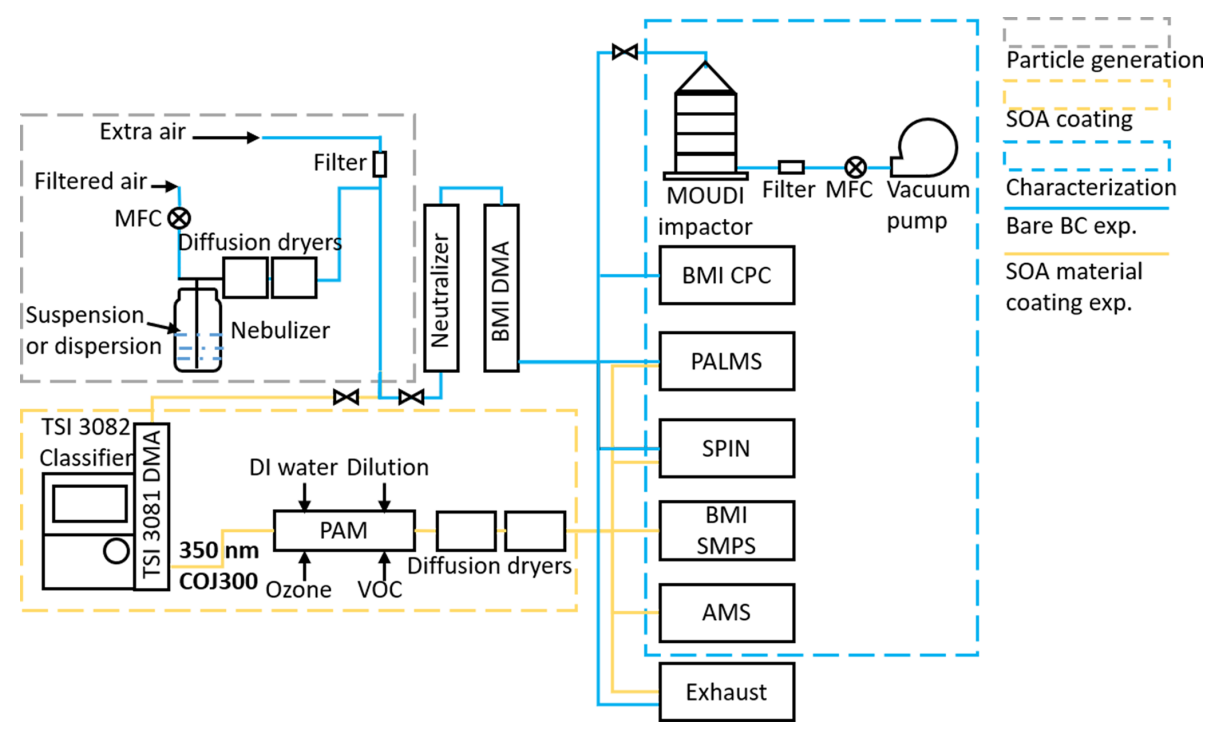

Figure 1. Schematic diagram of the experimental apparatus for bare BC particles (blue lines) and organic SOA coating experiments (yellow lines). The box with the gray dashed line encloses the particle-generation section, which is used for both bare BC and organic SOA coating experiments. The box with the yellow dashed line denotes the SOA coating section. The box with the blue dashed line is the aerosol characterization and test section.

text in Appendix A for more details). $d_{\mathrm{a}}=\sqrt{4 A_{\mathrm{a}}} / \pi$ is the diameter of a spherical aggregate that has the same projected area $\left(A_{\mathrm{a}}\right)$ as the $\mathrm{BC}$ aggregate (China et al., 2014). $\mathrm{AR}=L_{\max } / W_{\max }$ is the ratio between the longest dimension $\left(L_{\max }\right)$ of an aggregate periphery to the perpendicular maximum width $\left(W_{\max }\right.$, Fig. A2). Roundness $=\sqrt{4 A_{\mathrm{a}}} / \pi L_{\max }^{2}$ is used as a BC aggregate shape descriptor (e.g., China et al., 2013, 2015b; Kulkarni et al., 2016). Both AR and roundness are used to represent the shape deviation from a circle for which $\mathrm{AR}$ and roundness equal 1. Circularity $=4 \pi A_{\mathrm{a}} / p^{2}$ is a parameter used to describe the rugged level of an aggregate periphery $(p)$, with the rugged irregular periphery causing circularity smaller than $1 . D_{\mathrm{f}}$ depends on the primary particle number $(N)$ and the radius of gyration $\left(R_{\mathrm{g}}\right)$ of the aggregate (Mandelbrot, 1982). By using an ensemble approach, $N$ is found to be scaled with $\left(A_{\mathrm{a}} / A_{\mathrm{p}}\right)^{1.09}$, where $A_{\mathrm{a}}$ and $A_{\mathrm{p}}$ are the projected area of the aggregate and primary particles, respectively (Samson et al., 1987; Köylü et al., 1995; Oh and Sorensen, 1997; China et al., 2014). The approximate relation $L_{\max } / 2 R_{\mathrm{g}}=1.50 \pm 0.05$ is used to substitute $R_{\mathrm{g}}$, (Brasil et al., 1999), yielding $k\left(L_{\max } / \overline{d_{\mathrm{p}}}\right)^{D_{\mathrm{f}}}=\left(A_{\mathrm{a}} / A_{\mathrm{p}}\right)^{1.09} . D_{\mathrm{f}}$ can then be derived by a power law fit of scattered points between $L_{\max } / \overline{d_{\mathrm{p}}}$ and $\left(A_{\mathrm{a}} / A_{\mathrm{p}}\right)^{1.09}$ for each aggregate (Fig. A4). The $400 \mathrm{~nm}$ R2500U is more fractal than COJ300 and R330R with the same $d_{\mathrm{m}}$, together with $300 \mathrm{~nm}$ R2500U, which is indicated by $D_{\mathrm{f}}$. The project area, and the derived $d_{\mathrm{a}}$, are significantly affected by the degree of fractal particles, since highly fractal particles can have voids affecting the project area. COJ300 and R330, and $300 \mathrm{~nm}$ R2500U particles, are more spherical and compact than the fractal $400 \mathrm{~nm}$ R2500U, leading to larger $d_{\mathrm{a}}$ in comparison with $400 \mathrm{~nm}$ R2500U.

\subsubsection{Chemical composition characterization of single BC particle}

Qualitative chemical composition of size-selected BC particles was determined by PALMS. A detailed description of PALMS can be found elsewhere in the literature (Cziczo et al., 2006; Zawadowicz et al., 2015). PALMS is an online single particle mass spectrometer in which inlet particles are first aligned by an aerodynamic lens. Two Nd:YAG green $(532 \mathrm{~nm})$ laser beams separated by $33.6 \mathrm{~mm}$ are arranged at the bottom of the inlet, measuring particle velocity based on the time gap between the scattering signals. The velocity can be converted into vacuum aerodynamic diameter $\left(d_{\mathrm{va}}\right)$ from the measured time of flight (Cziczo et al., 2006; Fig. A5). A $193 \mathrm{~nm}$ ultraviolet (UV) excimer laser is then triggered, ablating and ionizing the particle. The ions of both refractory and volatile particle components are classified based on their mass to charge $(\mathrm{m} / \mathrm{z})$ ratio. PALMS provides either positive or negative polarity spectra for each particle. Particle ionization is often not quantitative. However, average ion ratios across many spectra allow a qualitative compositional comparison between two similar aerosol populations. Hundreds of spectra were collected for each soot sample to account for ionization differences caused by particle orientation difference (Murphy et al., 1998).

The chemical composition of the SOA-coated BC particle stream was analyzed online by PALMS and a highresolution time-of-flight aerosol mass spectrometer (HRToF-AMS; Aerodyne Research Inc.). More details about the AMS can be found in other literature (DeCarlo et al., 2006; Onasch et al., 2012); here, a brief introduction will be given. 
The AMS offers a quantitative average mass spectrum of an ensemble of aerosols. Particles entering the AMS first go through an aerodynamic lens inlet to form a particle beam. A mechanical chopper is used downstream of the inlet to control the sampling particle or particle-free period. The AMS employs a heated $600{ }^{\circ} \mathrm{C}$ tungsten surface to vaporize nonrefractory aerosols. Ionization is achieved using a universal $70 \mathrm{eV}$ electron ionization technique. Ionized species are detected by the time-of-flight mass spectrometry.

\subsection{SOA material coating on $\mathrm{BC}$ particles}

The $350 \mathrm{~nm}$ COJ300 BC was chosen to be the seed particle in all SOA coating experiments because of its effective IN activity and its higher particle concentration $\left(\sim 1 \times 10^{6} \mathrm{\# L}^{-1}\right)$ at the selected size, in comparison with other BCs $(1-3 \times$ $10^{4} \#^{-1}$ ).

Particle generation during the SOA coating experiments was identical to the bare $\mathrm{BC}$ experiments. The SOA coating experimental setup section is enclosed in the yellow dashed box of Fig. 1. As stated above, COJ300 BC particles were nebulized in an airflow of 2.2 SLPM, dried in two consecutive $43 \mathrm{~cm}$ silica gel diffusion dryers, and then $350 \mathrm{~nm} \mathrm{BC}$ particles were size-selected by a TSI 3081 DMA, with no impactor applied, and were directed to a potential aerosol mass (PAM) oxidation flow chamber (Kang et al., 2007; Lambe et al., 2011a; Liu et al., 2018). In the PAM reactor, the gas-phase VOC reacts with the $\mathrm{OH}$ radical and/or $\mathrm{O}_{3}$ (Lambe et al., 2011a; Zhang et al., 2018a) and subsequently forms SOA-coated BC particles. All flow rates were controlled by MFCs. The PAM chamber was operated at 4.4 SLPM total flow rate, including 2.2 SLPM BC aerosol flow, 1.0 SLPM O 3 carrier flow, 0.7 SLPM VOC carrier flow, and 0.5 SLPM humidified air. The residence time of particles in PAM under such flow conditions was approximately $260 \mathrm{~s}$. $\mathrm{O}_{3}$ was generated by irradiating 1.0 SLPM dry air through an external mercury lamp $(\lambda=185 \mathrm{~nm}$; Analamp low pressure Hg lamp; BHK Incorporated), with a concentration of 110 parts per million (ppm) inside the PAM chamber in our study (Lambe et al., 2011b). The typical $\mathrm{O}_{3}$ mixing ratio in the tropopause ranges between 0.1 and $1 \mathrm{ppm}$ (Fioletov, 2008; Gettelman et al., 2011). The ozone concentration in this study was higher than ambient concentration to expediate the reaction, given the short residence time of SOA within the PAM reactor (Lambe et al., 2011b; Zhang et al., 2015). A total of 0.5 SLPM humidified air was introduced into the chamber to react with the oxygen radical and produce $\mathrm{OH}$ radicals, with four mercury lamps $(\lambda=254 \mathrm{~nm}$; BHK Incorporated) mounted in Teflon-coated quartz cylinders inside the chamber to irradiate $\mathrm{O}_{3}$ and produce oxygen radical $\left(\mathrm{O}\left({ }^{1} \mathrm{D}\right)\right)$ via the $\mathrm{UV}$ photolysis reaction of $\mathrm{O}_{3}$ first $\left(\mathrm{O}_{3}+h v \rightarrow \mathrm{O}_{2}+\mathrm{O}\left({ }^{1} \mathrm{D}\right), \mathrm{O}\left({ }^{1} \mathrm{D}\right)+\mathrm{H}_{2} \mathrm{O} \rightarrow 2 \mathrm{OH}\right)$. The $\mathrm{OH}$ radical concentration can be varied by changing the four lamps' voltage. Two voltage levels, i.e., 10 and $3 \mathrm{~V}$, were tested in this study (indicated in Table 2 as suffixes -10 and
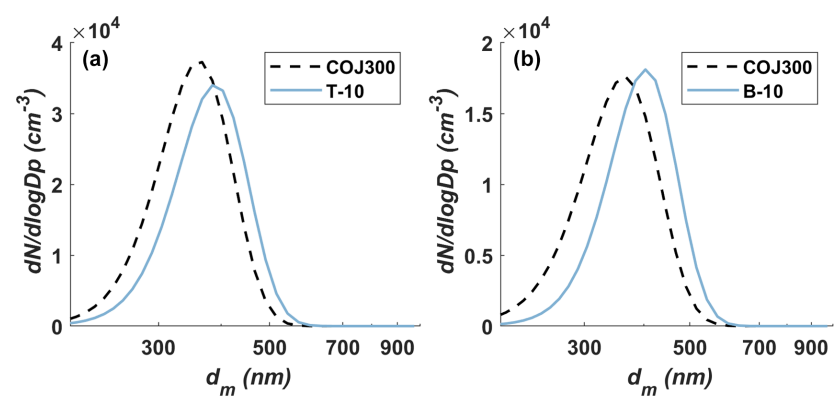

Figure 2. The modal diameter shift of $350 \mathrm{~nm}$ COJ300 BC particles after toluene (a) and $\beta$-caryophyllene (b) SOA coating. The dashed and solid lines are the fitted curves for bare uncoated and coated particles, respectively.

-3), corresponding to different $\mathrm{OH}$ exposure levels and atmospheric aging times, $\sim 10-15$ and $\sim 70-90 \mathrm{~d}$, based on previous calculations (Lambe et al., 2011a). The equivalent atmospheric aging times $t_{\mathrm{eq}}$ were calculated using the $\mathrm{OH}$ concentration of the PAM reactor $c_{\mathrm{OH}, \mathrm{PAM}}$, the residence time of the particles within the PAM, $t$, and the ambient $\mathrm{OH}$ concentration $c_{0}=1.0 \times 10^{6} \mathrm{~cm}^{-3}$ (Li et al., 2018), following the equation $t=c_{\mathrm{OH}, \mathrm{PAM}} \times t / c_{0} . c_{\mathrm{OH}, \mathrm{PAM}}$ was calculated based on $\mathrm{O}_{3}$ concentration and UV intensity and $\mathrm{RH}$ measured in real-time from the PAM reactor (Lambe et al., 2011a; Zhang et al., 2018a). The VOC was injected into a heated bulb by a syringe pump and mixed with 0.7 SLPM dry air. The particle size distributions downstream of the PAM were measured by a BMI scanning mobility particle sizer (BMI SMPS; comprised of model 2002 DMA and model 1700 CPC; Brechtel Manufacturing Inc.). The injection rate was controlled so that the modal size of the particles shifted from $350 \mathrm{~nm}$ bare BC particles to $400 \mathrm{~nm}$ SOA-coated BC particles, as illustrated in Fig. 2. The $400 \mathrm{~nm}$ SOA-coated BC particles were then dried to $\sim 16 \% \mathrm{RH}$ and kept below $25 \%$ by passing through two consecutive $43 \mathrm{~cm}$ silica gel diffusion dryers (DDU 570/H; Topas $\mathrm{GmbH}$ ). The PAM chamber was cleaned by flushing it with 10 SLPM clean air overnight after each experiment. In order to confirm the cleanliness of the chamber, particle concentration was measured before and after each experiment. The particle concentrations measured each day before experiments were below $70 \# \mathrm{cc}^{-1}$.

Table 2 summarizes all the SOA mixing IN experiments and the operating conditions. A peak shift from 350 to $400 \mathrm{~nm}$ and an increase in the $400 \mathrm{~nm}$ particle concentrations was observed for all experiments (Figs. 2 and B1 in Appendix B), implying that there is SOA coating on $\mathrm{BC}$ particles. The name prefixes BG, T, D, and B in Table 2 stand for background test, toluene SOA coating experiments, $n$-dodecane SOA coating experiments, and $\beta$-caryophyllene SOA coating experiments, respectively. The name suffixes $\mathrm{BC}, 0,3$, and 10 , and $\mathrm{s}$ denote seed $\mathrm{BC}$ only, $\mathrm{O}_{3}$ oxidation only, low $\mathrm{OH}$ exposure level $(3 \mathrm{~V})$, high $\mathrm{OH}$ exposure level $(10 \mathrm{~V})$, and SOA self-nucleation experiments, respectively. 
All three organic species were exposed to both low and high $\mathrm{OH}$ concentrations to investigate the effect of the oxidation level on SOA formation and IN activity. An extra $\mathrm{O}_{3}$ oxidation experiment (B-0) was performed for $\beta$-caryophyllene because it is highly reactive towards $\mathrm{O}_{3}$ and may form SOA in the absence of $\mathrm{OH}$. Self-nucleation IN experiments (-s) were performed for pure SOAs generated from each organic species to exclude the effect of nucleated pure SOAs mixing with SOA-coated BC particles.

\subsection{Ice nucleation measurement}

BC IN properties, including thermodynamic conditions at IN-onset and activation fraction (AF) as a function of $\mathrm{SS}_{i}$ and temperature, were measured with the SPectrometer for Ice Nuclei (SPIN; Droplet Measurement Technologies). The theory, dimension, and operating principles of SPIN can be found in previous studies (Garimella et al., 2016), and a brief description is given here.

SPIN is a continuous flow diffusion-chamber-style instrument comprising two flat, parallel stainless-steel walls for which the temperatures are independently controlled. The sampling flow rate of SPIN is 1.0 SLPM. Particles fed into SPIN are constrained by $\sim 9.0$ SLPM sheath gas within a lamina near the centerline of the SPIN chamber. Turbulent mixing at the injection point causes some particles to spread outside of the aerosol lamina centerline. Since particles experience lower RH as they spread outside of the lamina, correction factors, ranging from $\sim 1.9$ to 8.0 , were considered in previous studies (Garimella et al., 2017; Nichman et al., 2019; Wolf et al., 2019). Both walls are coated with $\sim 1 \mathrm{~mm}$ ice prior to experiments. At the beginning of each experiment, a linear temperature gradient and water vapor partial pressure field are established between the warm and cold walls. Supersaturation with respect to ice is achieved because of the exponential relationship between temperature and saturation vapor pressure (Borgnakke and Sonntag, 2013; Steane, 2016). For all the experiments in this study, SPIN was operated in a $\mathrm{SS}_{i}$ scanning mode (1.0 to 1.6) while keeping the lamina temperature $\left(-46\right.$ to $\left.-38^{\circ} \mathrm{C}\right)$ constant for each scan. The $\mathrm{SS}_{i}$ increased from 1.0 at a rate of 0.03 per minute by increasing the temperature gradient between the walls above the homogeneous IN threshold and then lowering it to ice saturation.

An optical particle counter (OPC) collects scattering signals for number counting and sizing, together with backward-scattering depolarized signals for phase discrimination at the SPIN chamber outlet. The size-detection range of the OPC is 0.5 to $15 \mu \mathrm{m}$. A machine learning algorithm, using the OPC scattering and laser depolarization signal (Garimella et al., 2016), was used to classify each particle as an inactivated aerosol or ice crystal over the course of an experiment.

We define the IN onset as $1 \%$ of particles being activated, i.e., $\mathrm{AF}=1 \%$, for a period of $10 \mathrm{~s}$ as activation. To account for aerosol spreading outside of the lamina where $\mathrm{SS}_{i}$ is the highest (Garimella et al., 2016), correction factors of 3.4 and 2.2 were applied for R2500U and R330R (Wolf et al., 2019). The correction factor was determined by taking the effect of morphology on particle behavior within SPIN lamina into consideration. Here, the AF is defined as the number concentration of ice crystals identified by the machine learning algorithm divided by the total particle number concentration entering SPIN. For the size-selected bare BC experiments, the total particle number concentration was measured by a CPC operating simultaneously with SPIN, while, for the SOA coating experiments, the total particle number concentration was integrated from the SMPS measurement.

\section{Results and discussion}

\subsection{Ice nucleation on bare BC particles}

Figure 3 summarizes the IN-onset temperature versus $\mathrm{SS}_{i}$ for $100-400 \mathrm{~nm}$ (a) R2500U, (b) COJ300, and (c) R330R $\mathrm{BC}$ particles, respectively. Representative error bars in black lines show 1 standard deviation of variability for SPIN lamina temperature and $\mathrm{SS}_{i}$ derived from experimental data, separately for each panel (Kulkarni and Kok, 2012).

As shown in Table 1 and Fig. 3, the three test BC types exhibit different particle morphology. The $400 \mathrm{~nm}$ R2500U has the smallest $D_{\mathrm{f}}(\sim 1.92)$, and COJ300 and R330R have larger $D_{\mathrm{f}}(\sim 2.34$ and 2.31 , respectively); R2500U is the most fractal BC, while COJ300 and R330R are more spherical and compact. Meanwhile, R2500U and COJ300 have similar $\overline{d_{\mathrm{pp}}}(34-35 \mathrm{~nm})$, and R330R has larger $(\sim 45 \mathrm{~nm})$ primary particles. The larger $\overline{d_{\mathrm{pp}}}$ of $200 \mathrm{~nm}$ R2500U (Table 1) might result from the blurring of primary particles under high magnification. Single particle surface area can be inferred by combining the fractal level and $\overline{d_{\mathrm{pp}}}$ together, and the decreasing order of the single particle surface area is $\mathrm{R} 2500 \mathrm{U}>\mathrm{COJ} 300>\mathrm{R} 330 \mathrm{R}$, which is in agreement with BET specific surface area data. The negative polarity mass spectra collected for $400 \mathrm{~nm}$ BC particles with PALMS are presented in Fig. A2. The spectra of all three BC types exhibit typical consecutive carbon peaks $(m / z=12,24,36$, etc.). The spectra of COJ300 show the presence of oxidized ions, such as $\mathrm{O}^{-}(m / z=16), \mathrm{OH}^{-}(m / z=17)$, and $\mathrm{COOH}^{-}$ $(m / z=45)$, which are highlighted in red in Fig. A2b. The frequency of the $m / z=16$ signal (Table 1) and PALMS O : C ratio result (Fig. A1) confirms that COJ300 is more oxidized than R2500U.

The results in Fig. 3a demonstrate that the particle size is relevant to the particle's IN ability, consistent with the $\mathrm{BC}$ heterogeneous IN ability enhancement triggered by increasing particle size in previous studies (Mahrt et al., 2018; Nichman et al., 2019). The $400 \mathrm{~nm}$ R2500U and R330R $\mathrm{BC}$ particles were able to nucleate ice below the homogeneous freezing threshold within the representative uncer- 
Table 2. Experiment conditions of BC and SOA coating experiments. The name prefixes BG, T, D, and B stand for background test, toluene SOA coating experiments, $n$-dodecane SOA coating experiments, and $\beta$-caryophyllene SOA coating experiments, respectively. The name suffixes $\mathrm{BC}, 0,3,10$, and s denote seed $\mathrm{BC}$ only, $\mathrm{O}_{3}$ oxidation only, low $\mathrm{OH}$ exposure level, high $\mathrm{OH}$ exposure level and SOA self-nucleation experiments, respectively. Note: ppb - parts per billion; ppm - parts per million.

\begin{tabular}{|c|c|c|c|c|c|c|}
\hline Experiment name & $\begin{array}{r}\mathrm{O}_{3} \\
(\mathrm{ppm})\end{array}$ & $\begin{array}{r}\text { OH UV lamp } \\
\text { voltage }(\mathrm{V})\end{array}$ & $\begin{array}{r}\text { Equivalent atmospheric } \\
\text { exposure (days) }\end{array}$ & $\begin{array}{l}\mathrm{BC} \\
\text { seed }\end{array}$ & \multicolumn{2}{|c|}{$\begin{array}{l}\text { VOC concentration } \\
(\mathrm{ppb})^{\mathrm{a}}\end{array}$} \\
\hline BG-BC & 0 & 0 & 0 & Y & - & - \\
\hline BG-0 & 110 & 0 & 0 & $\mathrm{Y}$ & - & - \\
\hline BG-10 & 110 & 10 & $70-90$ & $\mathrm{Y}$ & - & - \\
\hline $\mathrm{T}-10$ & 110 & 10 & $70-90$ & $\mathrm{Y}$ & Toluene & 6000 \\
\hline $\mathrm{T}-3$ & 110 & 3 & $10-15$ & $\mathrm{Y}$ & Toluene & 2000 \\
\hline $\mathrm{T}-\mathrm{s}^{\mathrm{b}}$ & 110 & 10 & $70-90$ & $\mathrm{~N}$ & Toluene & 4000 \\
\hline D-10 & 110 & 10 & $70-90$ & $\mathrm{Y}$ & $n$-dodecane & 2000 \\
\hline D-3 & 110 & 3 & $10-15$ & $\mathrm{Y}$ & $n$-dodecane & 500 \\
\hline$D-s^{b}$ & 110 & 10 & $70-90$ & $\mathrm{~N}$ & $n$-dodecane & 2000 \\
\hline B-10 & 110 & 10 & $70-90$ & $\mathrm{Y}$ & $\beta$-caryophyllene & 5000 \\
\hline B-3 & 110 & 3 & $10-15$ & $\mathrm{Y}$ & $\beta$-caryophyllene & 2300 \\
\hline B-0 & 110 & 0 & 0 & $\mathrm{Y}$ & $\beta$-caryophyllene & 5000 \\
\hline$B-s^{b}$ & 110 & 10 & $70-90$ & $\mathrm{~N}$ & $\beta$-caryophyllene & 5000 \\
\hline
\end{tabular}

${ }^{a}$ Estimated based on VOC volume injection rate. ${ }^{b}$ SOA self-nucleation experiments kept the same OH exposure level and SOA size distribution as the corresponding SOA coating experiments.

tainty range of the SPIN lamina $\mathrm{SS}_{i}$ in the temperature range of -46 to $-38^{\circ} \mathrm{C}$. The most spherical and oxidized COJ300 BC particles exhibited IN activity below homogeneous freezing threshold regardless of the particle size and temperature in this study. The IN-onset $\mathrm{SS}_{i}$ of all IN-active BC particles increases with increasing temperature. The trend is in agreement with previous BC IN studies on cirrus temperature regimes (DeMott et al., 1999; Möhler et al., 2005a; Koehler et al., 2009; Chou et al., 2013; Kulkarni et al., 2016; Mahrt et al., 2018; Nichman et al., 2019). The IN-onset $\mathrm{SS}_{i}$ of 200 and $300 \mathrm{~nm} \mathrm{R} 2500 \mathrm{U}$ and 100 and $200 \mathrm{~nm}$ R330R falls into the homogeneous freezing regime. The sharp AF increase in $400 \mathrm{~nm}$ R2500U and R330R along the expected homogeneous freezing threshold in Fig. 4 confirms that these two $\mathrm{BC}$ types nucleate ice via homogeneous freezing. We conclude that the lower size threshold, where the BC particles exhibit IN activity below the homogeneous freezing threshold at thermodynamic conditions relevant to cirrus, may well lie between 300 and $400 \mathrm{~nm}$ and 200 and $400 \mathrm{~nm}$ for R2500U and $\mathrm{R} 330 \mathrm{R}$ at around $-46^{\circ} \mathrm{C}$, respectively. The IN ability of differently sized R330R particles at higher temperatures (above $-45^{\circ} \mathrm{C}$ ) shows little difference, indicating that the lower size threshold for R330R is likely between 400 and $800 \mathrm{~nm}$ for temperatures between -44 and $-40^{\circ} \mathrm{C}$ (Nichman et al., 2019). The COJ300 BC is more IN active compared with R2500U and R330R. The COJ300 particles show IN ability below the homogeneous freezing threshold, down to $100 \mathrm{~nm}$ within the temperature range in this study; the lower size threshold for COJ300 is below $100 \mathrm{~nm}$. This finding agrees with the lower size limit between 100 and $200 \mathrm{~nm}$ for BC particles to act as an active INP, as reported by Mahrt et al. (2018).

The IN-onset results show no clear dependence on the particle fractal level and surface area, even though the more fractal and branching features of R2500U BC particles with larger surface areas do not clearly exhibit superior IN activity over R330R. Koehler et al. (2009) showed that IN was favored for oxidized hydrophilic BC, but too many hydrophilic active sites may bond water molecules, impeding ice embryo formation and thus impairing IN (Pruppacher and Klett, 2010). The surface-modified, highly dispersible, and spherical COJ300 with smaller $\overline{d_{\mathrm{pp}}}$ shows better IN efficiency than fractal $\mathrm{BC}$, which is consistent with the results of Mahrt et al. (2018) and Nichman et al. (2019), based on PCF mechanism. The physiochemical properties of COJ300 particles, including oxidized surface, appropriate $\overline{d_{\mathrm{pp}}}$, and compacted spherical morphology, may result in a higher probability of having cavities with appropriate size and hydrophilicity on particle surfaces (Mahrt et al., 2020). Such cavities can accommodate liquid water below bulk water saturation and initiate homogeneous freezing of liquid water via PCF pathways (Marcolli, 2014; David et al., 2019, 2020).

\subsection{Ice nucleation on BC coated with SOA material}

Figure 5 shows the IN-onset $\mathrm{SS}_{i}$ at which $1 \%$ of $400 \mathrm{~nm}$ SOA-coated COJ300 particles nucleate ice within the temperature range of -46 to $-38^{\circ} \mathrm{C}$. The IN-onset data of the bare $350 \mathrm{~nm}$ COJ300 particles (marked as + symbol) are also included to highlight the effect of SOA coating. IN-onset $\mathrm{SS}_{i}$ of pure SOA particles is shown separately as an asterisk to 

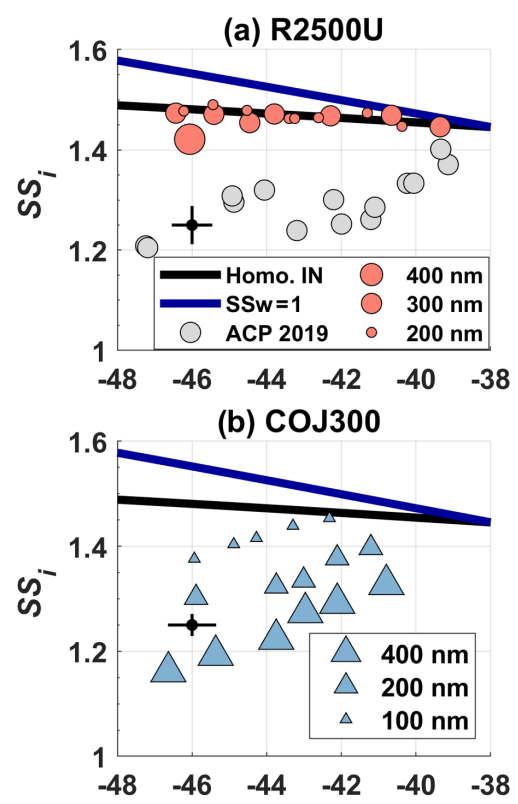

(c) R330R

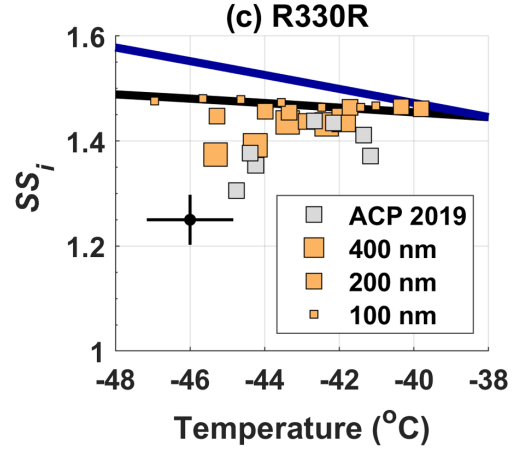

Figure 3. IN-onset $\mathrm{SS}_{i}(\mathrm{AF}=1 \%)$ phase diagram of bare (a) R2500U (circles), (b) COJ300 (triangles), and (c) R330R (squares), respectively. IN-onset data for $800 \mathrm{~nm} \mathrm{R} 2500 \mathrm{U}$ and $\mathrm{R} 330 \mathrm{R}$ from a previous study are included and denoted in gray markers (Nichman et al., 2019). Different marker sizes in this study correspond to different $d_{\mathrm{m}}$. Solid blue lines are the water saturation lines, and black lines are homogeneous freezing lines of $200 \mathrm{~nm}$ aqueous droplets (Koop et al., 2000). A representative error bar of SPIN lamina temperature and $\mathrm{SS}_{i}$ is given on the left of each panel.

rule out the possible ice formation below the homogeneous freezing threshold induced by pure SOA.

There exists no distinguishable difference between bare COJ300 and BC coated with highly oxidized toluene SOA (T-10 in Table 2) from -46 to $-44^{\circ} \mathrm{C}$. The toluene SOA mass spectrum in Fig. 6a exhibits a higher $m / z=44\left(\mathrm{COO}^{-}\right)$ and lower $m / z=43\left(\mathrm{C}_{3} \mathrm{H}_{7}^{-}\right)$fraction signal, indicating more oxidized organic species were generated during T-10 and T-3 experiments (Lambe et al., 2011b), agreeing with the previous study on toluene SOA (Liu et al., 2018).

The higher $\mathrm{O} / \mathrm{C}$ ratio (Fig. 7) of toluene-derived SOA may enhance the hygroscopicity of the particle (Lambe et al., 2011b; Zhao et al., 2016; Liu et al., 2018), with the potential to form an aqueous film on the $\mathrm{BC}$ surface and re-

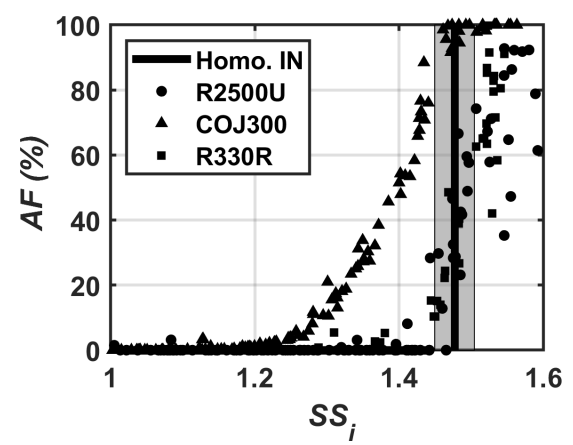

Figure 4. A representative $-45^{\circ} \mathrm{C} \mathrm{SS}_{i}$ scan of $400 \mathrm{~nm}$ bare BC particles, showing $\mathrm{AF}$ as a function of $\mathrm{SS}_{i}$. The black line is the homogeneous freezing threshold for $200 \mathrm{~nm}$ aqueous droplets at $-45^{\circ} \mathrm{C}$ (Koop et al., 2000). The gray shading indicates 1 standard deviation of variability for SPIN lamina $\mathrm{SS}_{i}$.

duce the IN ability of BC particles. On the other hand, Hinks et al. (2018) showed that toluene-derived SOA contained a significant amount of oligomers under dry laboratory conditions, similar to what we conducted in the PAM chamber in this study. Volkamer et al. (2001) proved that glyoxal, which could facilitate the oligomerization as described by Hinks et al. (2018), can be produced from a toluene reaction with $\mathrm{OH}$ as highly oxidized products. The slopes of T-10 and T-3 in Fig. 7 lie between 0 and 1 ( 0.71 and 0.99 for T-10 and T-3, respectively), suggesting that the oxygen and hydrogen atom addition, accompanied by carbon-carbon double bond and benzene ring breakage, might have happened during the toluene photooxidation experiments. These large oligomers could potentially reduce the hygroscopicity and alter the phase state of toluene SOA to be semisolid or solid within the temperature range we investigated in this work (DeRieux et al., 2018; Zhang et al., 2018c; Li et al., 2020) within which the SOA can still nucleate ice (Murray et al., 2010; Berkemeier et al., 2014; Y. Zhang et al., 2019b). The toluene SOA in T-10, with a $\mathrm{O}: \mathrm{C}$ ratio over 1 (Fig. 7), has most likely already transited into a solid or semisolid glassy state at the temperature range we investigated before entering SPIN (DeRieux et al., 2018). Therefore, it is very likely that $\mathrm{BC}$ particles are mostly stuck to or embedded in these glassy SOAs, with some bare BC parts exposed. Ice crystals may therefore form on the carbonaceous part of the partially coated particles whose IN-onset $\mathrm{SS}_{i}$ should be the same as bare COJ300. At temperatures above $-43{ }^{\circ} \mathrm{C}$, toluene SOAcoated BC particles nucleate ice at $\mathrm{SS}_{i} \sim 0.1$ to 0.15 higher than the IN-onset SSi of bare $350 \mathrm{~nm}$ COJ300 but still $\sim 0.15$ below the homogeneous freezing threshold. This might be due to the hygroscopicity enhancement of the toluene SOAcoated $\mathrm{BC}$ in $\mathrm{T}-10$. BC coated by $\sim 10-15$ equivalent days of atmospherically oxidized toluene SOA (T-3 in Table 2) is less IN active than those particles coated by highly oxidized toluene SOA (T-10) at around -46 and $-43^{\circ} \mathrm{C}$. This might also be attributed to the oxidation level and the cor- 


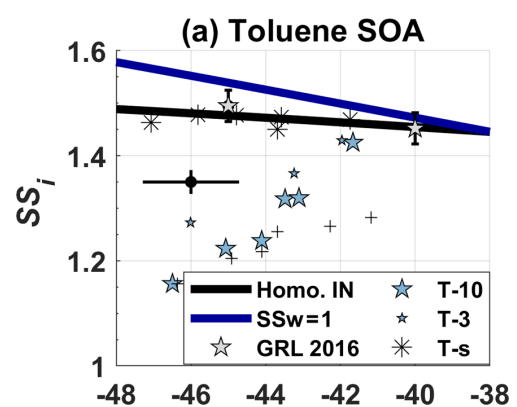

(b) n-dodecane SOA

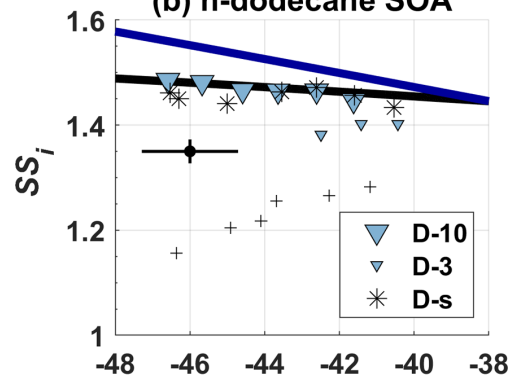

(c) $\beta$-caryophyllene SOA

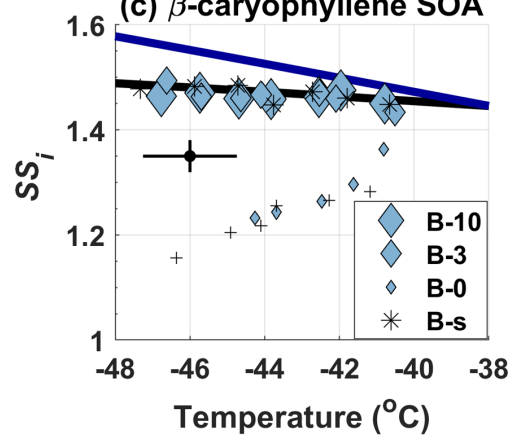

Figure 5. IN-onset $\mathrm{SS}_{i}$ phase diagram of $350 \mathrm{~nm}$ COJ300 BC particles coated with (a) toluene SOA, (b) $n$-dodecane SOA, and (c) $\beta$ caryophyllene SOA. Different symbol sizes denote different $\mathrm{OH}$ exposure levels. IN-onset $\mathrm{SS}_{i}$ of $350 \mathrm{~nm}$ bare COJ300 is shown with black plus symbols for comparison. Pure SOA IN-onset $\mathrm{SS}_{i}$ are presented as asterisks for each organic species, respectively. The solid blue and black lines are water saturation lines and homogeneous lines for $200 \mathrm{~nm}$ aqueous droplets (Koop et al., 2000), respectively. A representative SPIN lamina temperature and $\mathrm{SS}_{i}$ error bar is given on the left side of each panel. The toluene-SOA-coated diesel BC IN data from Kulkarni et al. (2016) are also included for comparison.

responding phase state difference between the SOA generated from the T-10 and T-3 experiments, which is beyond the scope of this study and requires further detailed phase transition study for toluene SOA. Overall, two competing effects, i.e., the hygroscopicity enhancement deactivating $\mathrm{BC}$ IN ability and toluene SOA glass-phase transition producing $\mathrm{BC}$ that is stuck together or partly coated may make our toluene SOA coating IN onset move towards, but not fully in, the homogeneous freezing regime. The toluene-SOA-coated diesel combustion BC (Kulkarni et al., 2016), however, nucleate ice near the homogeneous threshold, as indicated in
Fig. 5a. This might be due to the much thicker $(90 \mathrm{~nm})$ organic coating in their study compared to the $25 \mathrm{~nm}$ coating of this work, leading to a complete coverage of BC surface.

The IN-onset $\mathrm{SS}_{i}$ of highly oxidized $n$-dodecane-SOAcoated COJ300 particles (D-10 in Table 2) in Fig. 5b shows that these particles nucleate ice homogeneously between -46 and $-42^{\circ} \mathrm{C}$. BC coated by slightly oxidized $n$-dodecane SOA (D-3 in Table 2) nucleates ice nominally lower than the homogeneous freezing threshold between -43 and $-40^{\circ} \mathrm{C}$. As shown in Fig. 5 c, the IN-onset $\mathrm{SS}_{i}$ of $\mathrm{OH}$-oxidized $\beta$ caryophyllene SOA-coated COJ300 particles (B-10 and B3 in Table 2) is in the homogeneous freezing regime. The mass spectra in Fig. $6 \mathrm{~b}$ and $\mathrm{c}$ exhibit a large fraction of signals at $m / z=15\left(\mathrm{CH}_{3}^{-}\right), 29\left(\mathrm{C}_{2} \mathrm{H}_{5}^{-}\right), 43\left(\mathrm{C}_{3} \mathrm{H}_{7}^{-}\right)$, and 55 $\left(\mathrm{C}_{4} \mathrm{H}_{7}^{-}\right)$for $n$-dodecane and $\beta$-caryophyllene SOA coating experiments in this study, implying the formation of less oxidized aliphatic fragments during these experiments (Lambe et al., 2011b). The $\mathrm{H} / \mathrm{C}$ and $\mathrm{O} / \mathrm{C}$ values of $n$-dodecane and $\beta$-caryophyllene SOA coating in Fig. 7 are smaller than that of toluene SOA, which are in agreement with previous studies (Simonen et al., 2017; Li et al., 2019; Pereira et al., 2019). The slopes of the $\mathrm{H} / \mathrm{C}$ and $\mathrm{O} / \mathrm{C}$ values between these two types of SOAs and their respective two precursors (Fig. 7) are in the range between -1 and 0 , which is consistent with the simultaneous formation of carboxylic acid functional groups and $\mathrm{C}-\mathrm{C}$ bond breakage (Heald et al., 2010; Lambe et al., 2011b). The addition of the carboxylic acid group may enhance the hygroscopicity of $n$ dodecane and $\beta$-caryophyllene SOA, and the hygroscopicity is further enhanced with more $\mathrm{OH}$ exposure (Frosch et al., 2013; Yee et al., 2013; Schilling et al., 2015; Bé et al., 2017). We conclude that $\mathrm{BC}$ with $\mathrm{OH}$-oxidized $n$-dodecane and $\beta$-caryophyllene SOA coatings, regardless of the oxidation level, may condense on the $\mathrm{BC}$ surface and form organic films, leading to ice formation in the homogeneous regime. However, COJ300 BC coated with $\mathrm{O}_{3}$ oxidized $\beta$ caryophyllene SOA (B-0 in Table 2) shows no significant alternation in the IN ability, as shown in Fig. 5c. Unlike the $\mathrm{OH}$ oxidation of $\beta$-caryophyllene where fragmentation happens, $\mathrm{O}_{3}$ addition is very likely to happen first on the carboncarbon double bond of $\beta$-caryophyllene in B-0, leading to a formation of semisolid or solid SOA (Nguyen et al., 2009; Winterhalter et al., 2009), as illustrated in Fig. 7, with a slope between 0 and 1 . As with the case of T-10, such semisolid or solid SOA might collide and stick with BC particles, leaving some bare carbonaceous surfaces that can nucleate ice, following the IN pattern of COJ300 BC.

The experimental results are attributed to two factors, namely organic coating and SOA-phase state. Previous studies controlling the combustion fuel-air ratio produced $\mathrm{BC}$ particles occupying different $\mathrm{OC}$ content fractions, among which the higher organic content $\mathrm{BC}$ had amorphous organic surfaces (Möhler et al., 2005b; Crawford et al., 2011; Mahrt et al., 2018). In these studies, shifts from heterogeneous to homogeneous freezing with increasing OC content have been 

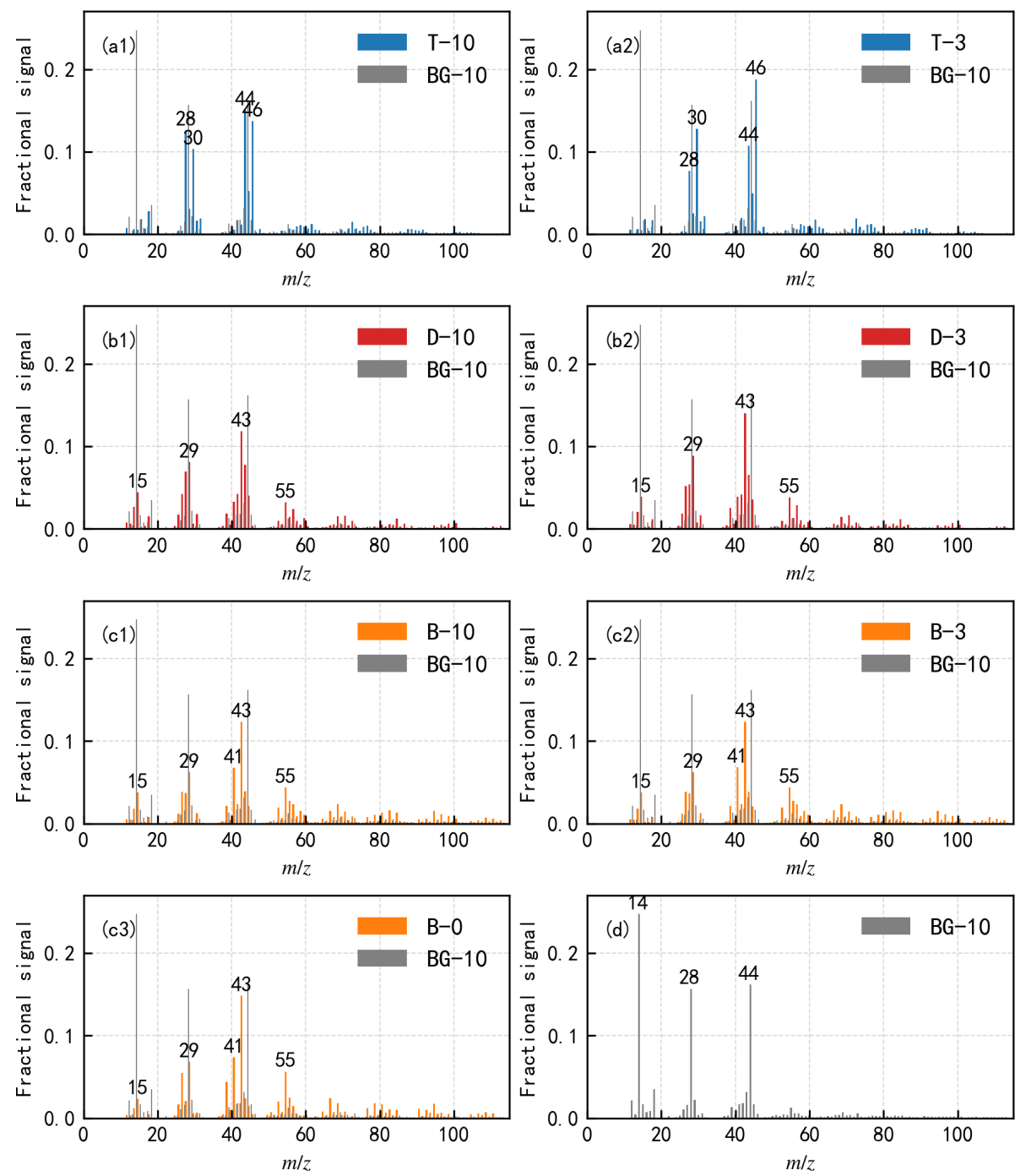

Figure 6. Normalized aerosol mass spectrometer (AMS) mass spectra of COJ300 BC particles coated with (a) toluene SOA, (b) $n$-dodecane SOA, (c) $\beta$-caryophyllene SOA, and (d) bare COJ300 BC particles. More oxidized SOA is generated when toluene acts as a precursor, while less oxidized SOAs are generated when $n$-dodecane and $\beta$-caryophyllene act as precursors in this study, as indicated by the different fractions of $m / z=43$ and 44, respectively (Lambe et al., 2011b; Ng et al., 2011; Canagaratna et al., 2015). The absolute organic mass loading present in the bare $\mathrm{COJ} 300 \mathrm{BC}$ experiment is less than $1 \%$ of the organic mass loading from the other three types of SOA coating experiments.

observed. Kulkarni et al. (2016) reported that an $80 \mathrm{~nm} \alpha$ pinene SOA coating can suppress the IN ability of $120 \mathrm{~nm}$ diesel BC particles. However, studies show that, as the phase state of the organic coating changes below a certain threshold, especially near the glass-transition temperature, these organic coatings might be able to heterogeneously nucleate ice (Murray et al., 2010; Berkemeier et al., 2014; Y. Zhang et al., 2019b). The suppression of the BC IN ability by organic coating was attributed to the coverage of surface-active sites and the filling of pores on the BC surface when the volatility of the organic coating was relatively high and might have presented in the liquid phase. Certain SOA coatings in this study are less oxidized and, thus, may similarly impair BC IN ability due to their relatively high volatility, as Docherty et al. (2018) and Hildebrandt Ruiz et al. (2015) showed in an inverse correlation between the volatility and oxidation state. Our results suggest that less oxidized SOA $(n-$ dodecane and $\beta$-caryophyllene-derived SOA from photooxidation), with 200 to 4000 times the typical tropospheric SOA (Tsigaridis and Kanakidou, 2003; Heald et al., 2008; Hodzic et al., 2016) mass loading in the PAM chamber $(\sim 2000$ to $4000 \mathrm{\mu g} \mathrm{m}^{-3}$ ), is more likely to condense on seed particles and form fully coated $\mathrm{BC}$ particles, moving IN-onset $\mathrm{SS}_{i}$ to the homogeneous regime, while $\beta$-caryophyllene SOA oxidized by $\mathrm{O}_{3}$ does not alter the $\mathrm{SS}_{i}$ of the soot particles. In addition, more oxidized SOA (toluene-derived SOA from photooxidation) with potentially more oligomer formation, 


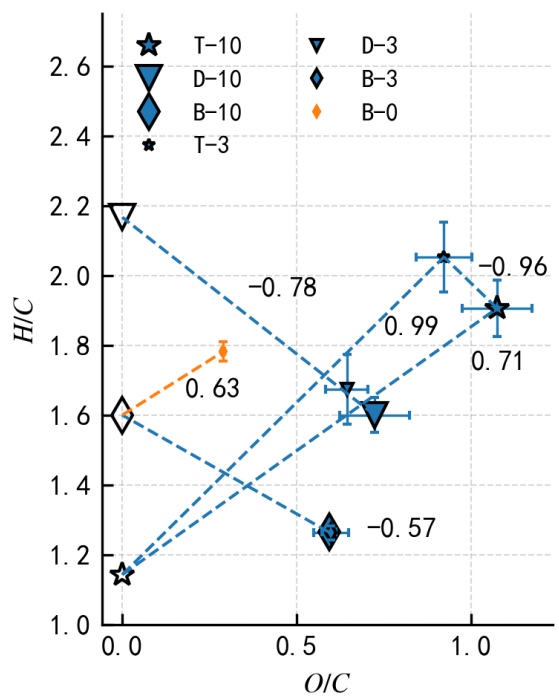

Figure 7. The elemental $\mathrm{H} / \mathrm{C}$ ratio as a function of the $\mathrm{O} / \mathrm{C}$ ratio for three pure organic precursors (hollow symbols) and corresponding COJ300 BC particles seeding SOA inside the PAM reactor (filled symbols). Different symbol sizes denote different $\mathrm{OH}$ exposure levels. The negative slopes of SOA coating experiments are consistent with the simultaneous carboxylic acid group addition and C-C single bond breakage (Heald et al., 2010; Lambe et al., 2011b).

moves IN-onset $\mathrm{SS}_{i}$ towards, but still below, the homogeneous freezing threshold.

\section{Atmospheric implications}

$\mathrm{BC}$ particles emitted from combustion sources (such as aeroengines) are carbonaceous nanoscale fractal aggregates with a primary particle diameter of $20-50 \mathrm{~nm}$ (Bockhorn et al., 2009; Vander Wal et al., 2014). These BC particles can remain suspended in the atmosphere for days and might undergo compaction and atmospheric aging, such as oxidation and mixing with atmospheric organic species. This study focuses on the impact of morphology, particle size, and mixing state on the IN ability of BC-containing aerosols. Three BC proxies were chosen to represent freshly emitted (in other words, unoxidized and more fractal) BC (R2500U), unoxidized compacted BC (R330R), and atmospheric chemically aged BC (COJ300). The morphological characteristics are within the value range of typical amounts of $\mathrm{BC}$ emitted from combustion sources and those collected in field observations (e.g., Lapuerta et al., 2007; China et al., 2013, 2014; Vander Wal et al., 2014; China et al., 2015b; Y. Zhang et al., 2019a). BC primary particle size range in this study lies between 10 and $70 \mathrm{~nm}$, with a modal size around 25 to $40 \mathrm{~nm}$, consistent with previous primary particle studies on combustion BC (e.g, Smekens et al., 2005; Liati et al., 2016; Joo et al., 2018). Previous field observations of transportation emissions and biomass burning reported that ambient $\mathrm{BC}$ oc- cupied $d_{\mathrm{a}}$, circularity, and roundness in the range of 130 to $940 \mathrm{~nm}, 0.19$ to 0.55 , and 0.32 to 0.6 , respectively (China et al., 2013, 2014, 2015a, b), overlapping with the range in this work. R2500U is similar to the fresh BC emitted from B737 at medium power, when burning conventional jet fuel, in terms of morphology characteristics (Vander Wal et al., 2014). The primary particle size is consistent with BC emitted from prevalent gas turbine engines (Huang and Vander Wal, 2013). Findings in this study can be relevant to airborne aircraft emissions and ground emissions carried by updrafts to the tropopause.

The IN results for bare $\mathrm{BC}$ particles show a dependence on particle size and surface chemistry, but the role of the fractal level seems to be of limited importance. The lower size limit of bare $\mathrm{BC}$ in exhibiting IN activity is between 300 and $400 \mathrm{~nm}$ for R2500U at $-46^{\circ} \mathrm{C}$. This is important for freshly emitted $\mathrm{BC}$ from aircraft engines and ground transportation, which is generally fractal and smaller than $200 \mathrm{~nm}$, with a modal size ranging from 20 to $100 \mathrm{~nm}$ (Kittelson, 1998; Wey et al., 2006; Anderson et al., 2011; Wang et al., 2016; Moore et al., 2017; Raza et al., 2018; Awad et al., 2020). It is unlikely that small, freshly emitted BC will activate as INP in aircraft plumes below the homogeneous freezing threshold if they possess similar physicochemical properties to R2500U. The smallest size for compacted BC (R330R) to activate as INPs lies between 200 and $400 \mathrm{~nm}$ at $-46^{\circ} \mathrm{C}$. However, the IN ability of small BC particles may be enhanced after cloud cycles, during which fractal $\mathrm{BC}$ geometries may collapse, forming PCF-favoring morphology (Mahrt et al., 2020). Apart from the most spherical morphology, the smaller $d_{\mathrm{pp}}$ of COJ300 may also offer a higher probability of forming smaller mesopores with the appropriate size to accommodate ice crystal formation below water saturation, with particles down to $100 \mathrm{~nm}$ acting as efficient INP. Pores formed by $\mathrm{BC}$ with larger $d_{\mathrm{pp}}$ might be too wide to accommodate liquid water in our experimental conditions. Besides, the COJ300 IN results imply that ice crystal formation may favor oxidized hydrophilic surfaces, confirming the importance of surface hydrophilicity for pore filling in the PCF mechanism (David et al., 2019; David et al., 2020). This suggests that long-lived atmospheric BC particles, after being oxidized and compacted, may act as efficient INP.

To simulate atmospheric aging, toluene, $n$-dodecane, and $\beta$-caryophyllene were chosen to represent anthropogenic and biogenic SOA precursors (Atkinson and Arey, 2003; Hu et al., 2008; Ding et al., 2014). Toluene-derived SOA coatings impede $\mathrm{BC}$ heterogeneous IN activity slightly, while $n$ dodecane and $\beta$-caryophyllene-derived SOA coatings cause $\mathrm{BC}$ particles to nucleate ice homogeneously. BC emitted from aircraft and vehicles is likely to be coated by toluene and $n$-dodecane-derived SOA (e.g., Beyersdorf et al., 2012, 2014; Timko et al., 2014). According to our experimental results, even though such a coating can facilitate particle growth, SOA-coated particles are more likely to nucleate ice near the homogeneous freezing threshold. 
The conclusions drawn here for $\mathrm{BC}$ proxies may deviate from genuine $\mathrm{BC}$ emitted from combustion sources. Nonetheless, BC surrogates are often used in research to mimic aircraft-emitted BC for their similarity and availability (e.g., Persiantseva et al., 2004). Additional IN studies, over a wider temperature range, would also be required for the proxies to firmly verify the PCF mechanism; the question of whether the studied IN is depositional or in fact the homogeneous IN of liquid water in pores and cavities remains to be answered due to the limited temperature range investigated in this study.

\section{Summary}

The IN ability of size-selected (100-400 nm) BC particles with different morphologies and surface chemistry and $\mathrm{BC}$ particles coated with toluene, $n$-dodecane, and $\beta$ caryophyllene-derived SOA has been systematically investigated in the cirrus temperature regime $\left(-46\right.$ to $\left.-38^{\circ} \mathrm{C}\right)$. Three aerosolized BC proxies were selected to represent particle morphology at different atmospheric aging stages, i.e., freshly emitted (R2500U), atmospheric compacted (R330R), and atmospheric compacted and oxidized (COJ300). The IN activity was investigated in relation to particle size, morphology, surface chemistry, SOA precursor type, and $\mathrm{OH}$ exposure level.

The results show that the lower size limit for BC particles to exhibit IN activity varies between BC type. At $400 \mathrm{~nm}$, freshly emitted and compacted BC particles nucleate ice near the homogeneous freezing threshold. Ice crystals form on most spherical, surface-modified hydrophilic BC at $\mathrm{SS}_{i}$ as low as 1.15. The onset of some IN occurs below the homogeneous freezing threshold, as opposed to purely homogeneous freezing, for some BC types between 100 and $200 \mathrm{~nm}$, in some cases below $100 \mathrm{~nm}$. We conclude that BC IN favors larger, spherical particles with oxidized hydrophilic surfaces. The highly fractal BC particles did not necessarily act as superior INP over more spherical ones as would normally be anticipated from surface area. This could be attributed to PCF occurring in the pores and cavities with the appropriate size offered by compacted BC particles.
Toluene-derived SOA coatings increase bare BC IN-onset $\mathrm{SS}_{i}$ by $0.1-0.15$, but this is still below the homogeneous freezing threshold. Slightly oxidized toluene SOA coatings seem to have a stronger deactivation effect on BC IN ability than highly oxidized toluene SOA, which might be caused by oligomer formation and the phase state transition of toluene SOA material under different oxidation levels. The higher volatility of $\mathrm{OH}$-oxidized $n$-dodecane and $\beta$-caryophyllene SOA may enhance the coating thickness and further elevates the IN-onset $\mathrm{SS}_{i}$ into the homogeneous freezing regime. This might be due to SOA material filling the pores on BC surfaces and leading to IN near the homogeneous regime. $\mathrm{O}_{3}$-oxidized $\beta$-caryophyllene SOA does not seem to affect BC IN activity. $\mathrm{OH}$ exposure levels of $n$-dodecane and $\beta$ caryophyllene SOA coating experiments, from an equivalent atmospheric exposure time range of 10 to $90 \mathrm{~d}$, shows no significant difference. Our study broadens the aging processes of atmospheric BC particles and may offer the basis for a better prediction of their IN activity and contribution to cirrus cloud formation. We suggest that future studies should focus on the IN activity of realistic combustion particles (aircraft, vehicles, biomass burning, etc.) and advanced single particle characterization for validation of the PCF mechanism. 
Appendix A: BC physio-chemical properties characterization
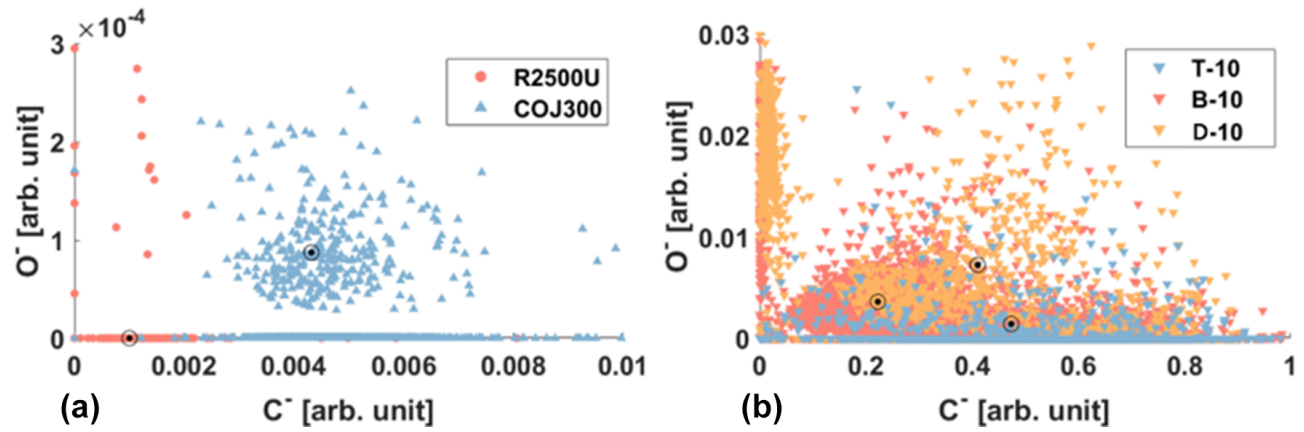

Figure A1. Negative polarity oxygen and carbon peak areas from PALMS for (a) $400 \mathrm{~nm}$ R2500U and COJ300 BC. (b) SOA-coated BC particles. Cluster centroid denoted as a bull's eye. Generally, the probability of $\mathrm{O}^{-}$signal presence in COJ300 is an order of magnitude higher than R2500U.
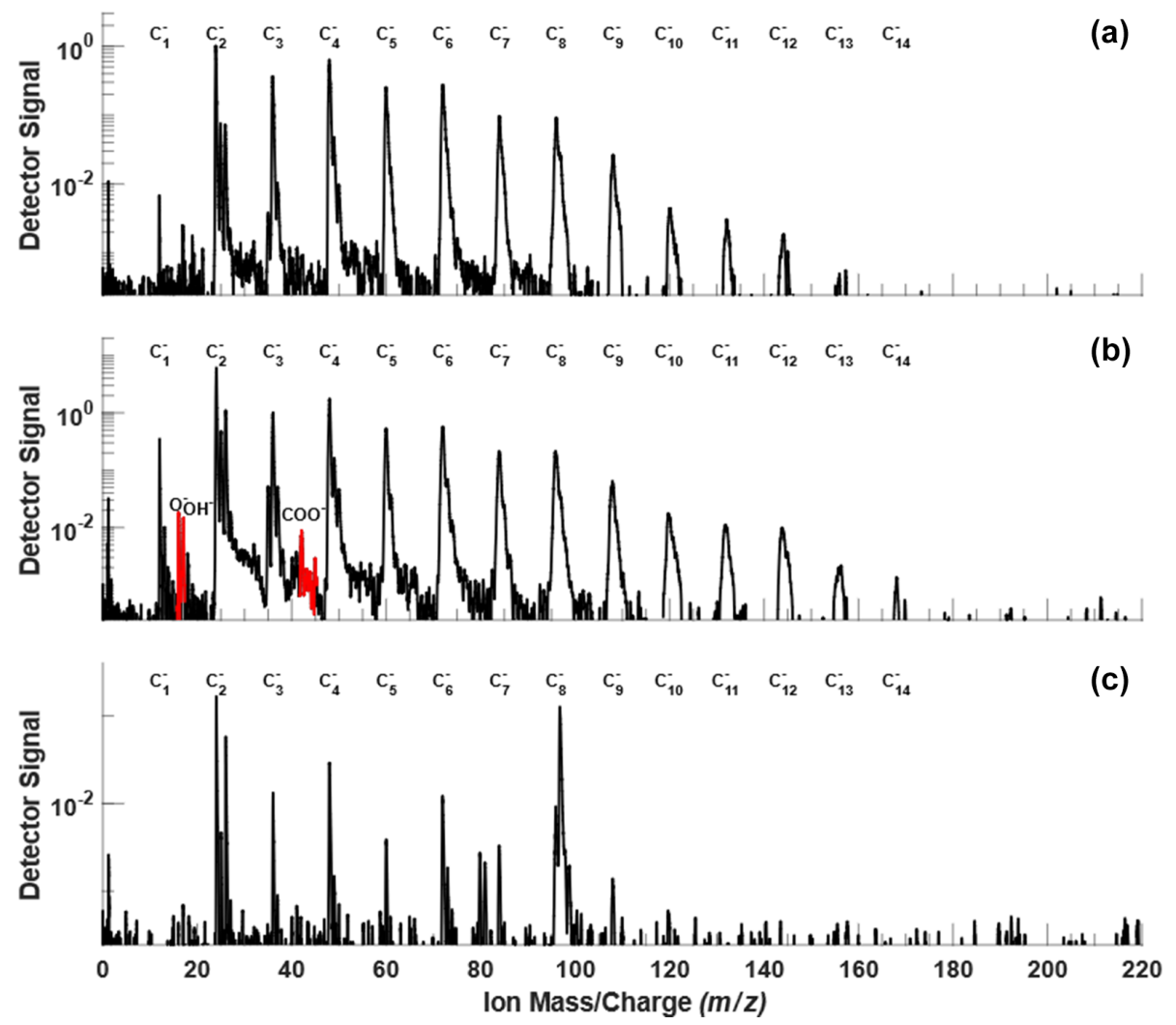

Figure A2. Representative negative ion PALMS mass spectra of bare size selected (a) R2500U, (b) COJ300, and (c) R330R BC particles, with a modal size of around $400 \mathrm{~nm}$. The ions indicative of oxidized material $(\mathrm{m} / z=16,17$, and 45$)$ are highlighted in red. 


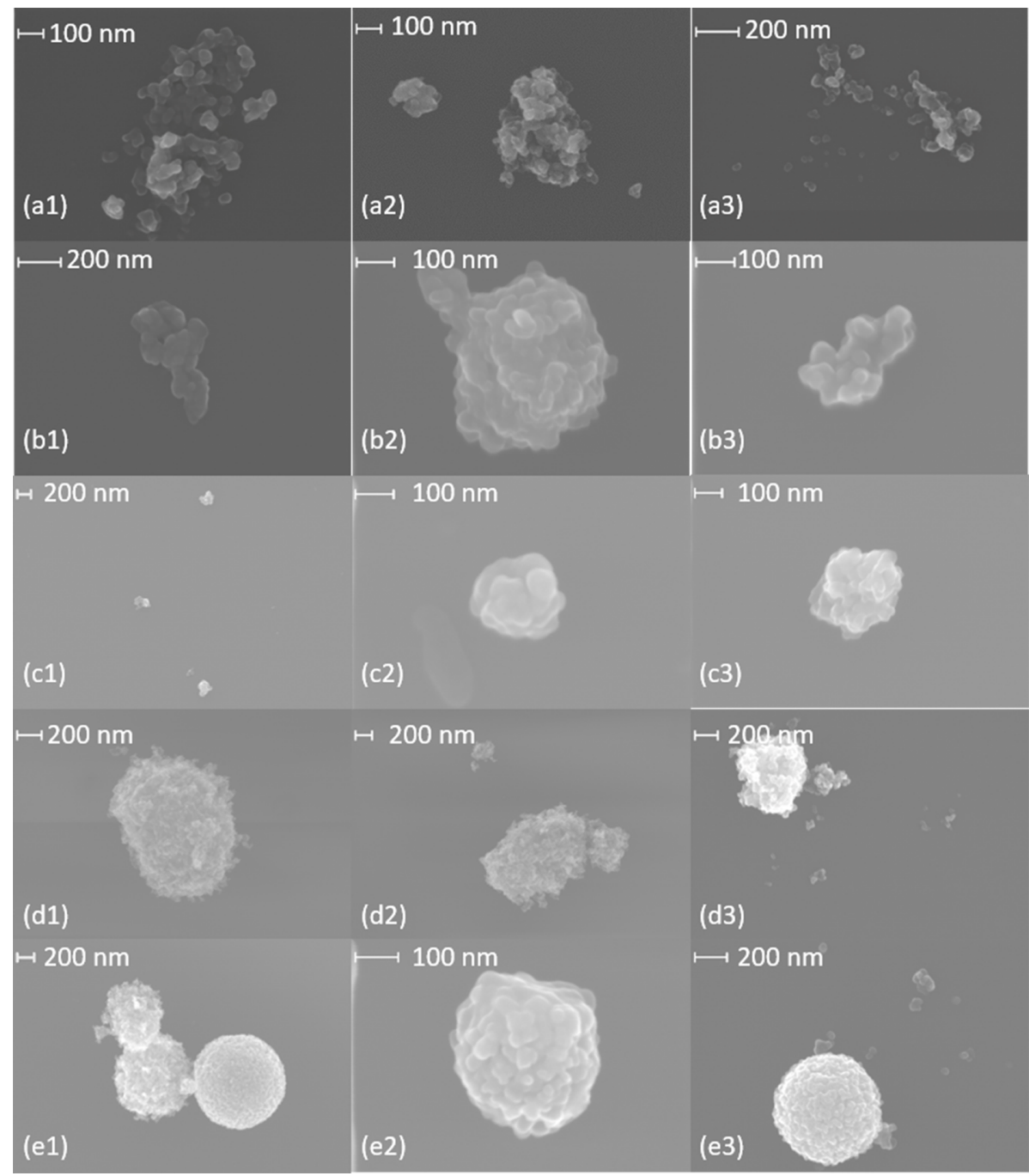

Figure A3. SEM images of (a) $400 \mathrm{~nm}$ R2500U, (b) $300 \mathrm{~nm}$ R2500U, (c) $200 \mathrm{~nm}$ R2500U, (d) $400 \mathrm{~nm}$ R330R, and (e) $400 \mathrm{~nm}$ COJ300.

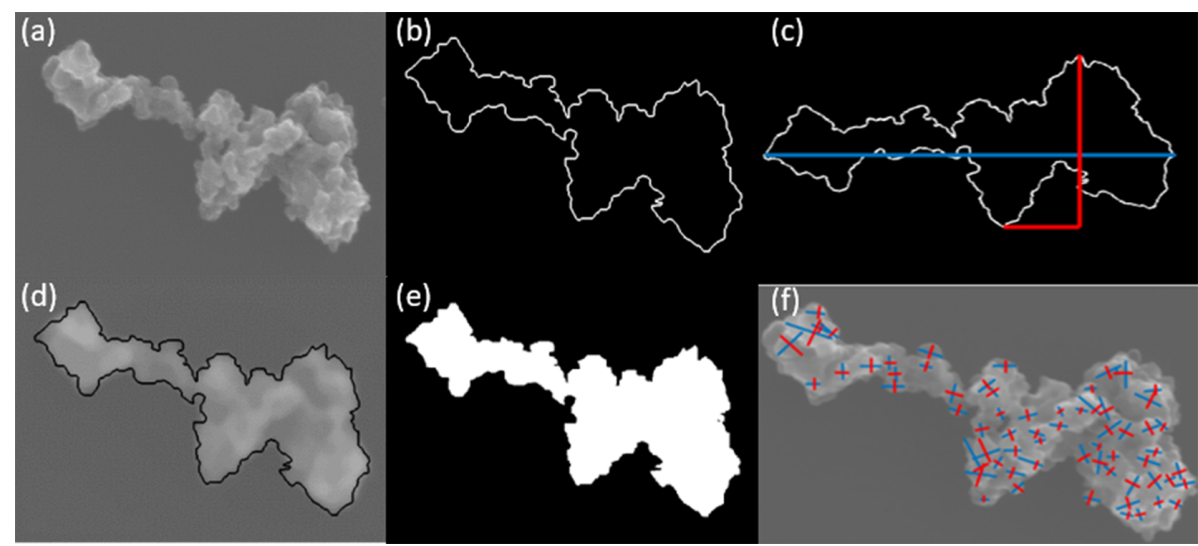

Figure A4. Example of the processing of SEM images. (a) Original image. (b) A manual drawing of an approximate aggregate outline in order to (c) obtain the longest dimension $\left(L_{\max }\right)$ of an aggregate periphery to the perpendicular maximum width ( $\left.W_{\text {max }}\right)$. (d) Validation of the periphery. (e) Use of the binary figure to obtain project aggregate area $\left(A_{\mathrm{a}}\right)$. (f) Measurement of the primary particle diameter $\left(d_{\mathrm{pp}}\right)$. 
BC aggregate parameters, including $L_{\max }$ and $W_{\max }$, perimeter, and project area, are determined by manually drawing the periphery of the aggregate, as shown in Fig. A4a-e. The primary particle diameter is determined by identifying the boundary of the BC primary particle in the SEM image. After manual selection of the start and end points of a primary particle's length and width, respectively, the distance between these points is calculated automatically and recorded. The primary particle diameter equals to the geometric mean of the length and width. The primary particle size distribution of a specific BC type and size can then be obtained by categorizing the primary particle diameters into different size bins and counting the frequency, as shown in Fig. A5. BC primary particle size distribution obeys normal distribution. The coefficients and goodness of normal distribution fits are shown in Table A1.

Table A1. Coefficients and goodness for the normal primary particle size distribution fit. The $95 \%$ confidence intervals are enclosed in parentheses.

\begin{tabular}{lrrr}
\hline BC type and size & Geometric mean diameter $(\mathrm{nm})$ & Geometric standard deviation $(\mathrm{nm})$ & $R^{2}$ \\
\hline $200 \mathrm{~nm}$ R2500U & $36.85(35.97,37.73)$ & $14.30(13.05,15.55)$ & 0.98 \\
$300 \mathrm{~nm}$ R2500U & $30.50(29.43,31.56)$ & $12.70(11.20,14.21)$ & 0.96 \\
$400 \mathrm{~nm}$ R2500U & $29.06(28.25,29.97)$ & $12.70(11.55,13.85)$ & 0.98 \\
$400 \mathrm{~nm}$ COJ300 & $30.41(29.54,31.29)$ & $12.11(10.88,13.35)$ & 0.97 \\
$400 \mathrm{~nm}$ R330R & $40.39(33.44,47.34)$ & $16.32(15.06,17.58)$ & 0.95 \\
\hline
\end{tabular}
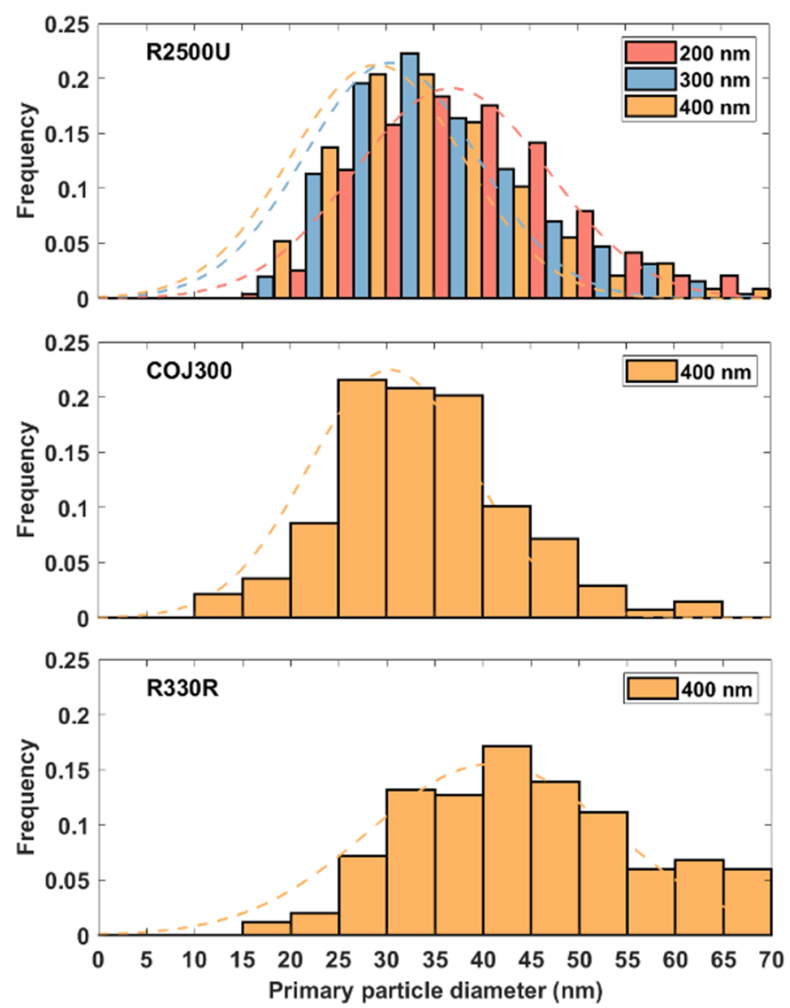

Figure A5. Primary particle size distributions for the selected BC particle types. The dashed lines are the fitted normal distribution curves. 
(a) $200 \mathrm{~nm} \mathrm{R2500U}$

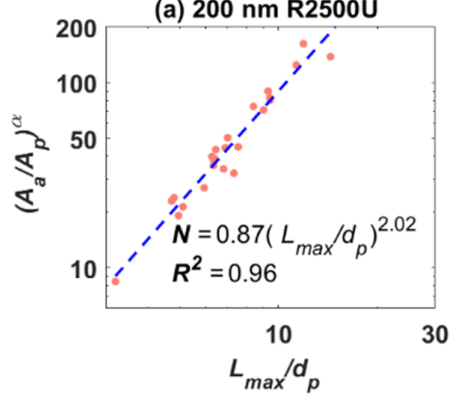

(b) $300 \mathrm{~nm}$ R2500U

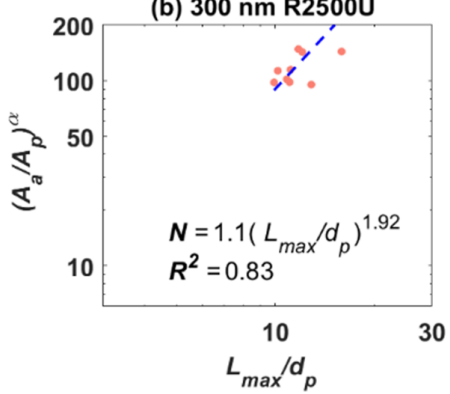

(c) $400 \mathrm{~nm}$ R2500U

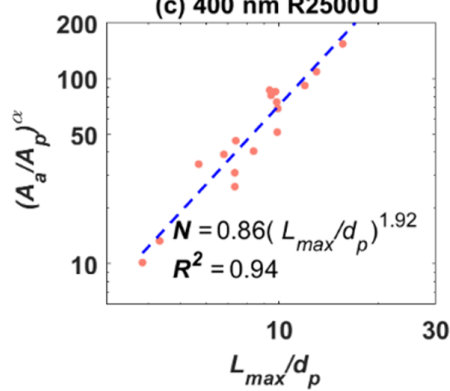

Figure A6. Power law fit to obtain 3-D fractal dimensions of (a) $200 \mathrm{~nm}(N=25)$, (b) $300 \mathrm{~nm}(N=12)$, and (c) $400 \mathrm{~nm}(N=21) \mathrm{R} 2500 \mathrm{U}$ BC particles. More than 10 aggregates were analyzed for each size.
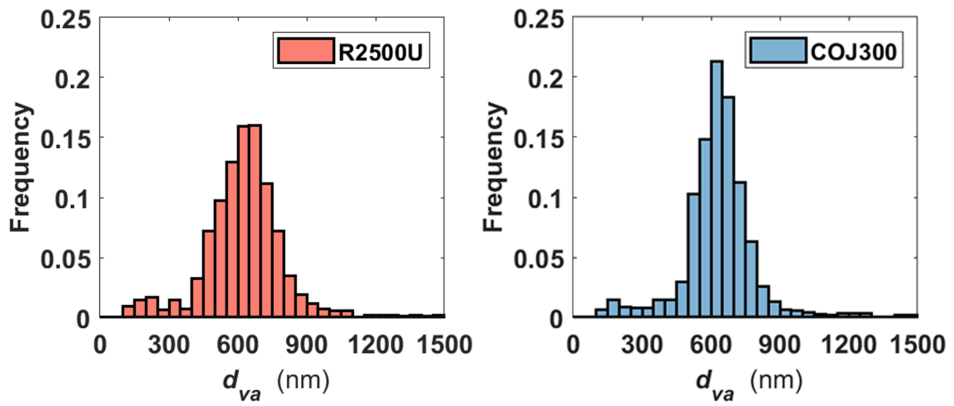

Figure A7. Vacuum aerodynamic diameter $\left(d_{\mathrm{va}}\right)$ derived from PALMS for $400 \mathrm{~nm}$ R2500U and COJ300 (Cziczo et al., 2006). 


\section{Appendix B: SOA coating experiments}

Table B1. Organic compounds engaged in this study. The parameters are taken from room temperature data.

\begin{tabular}{|c|c|c|c|c|c|}
\hline Compound & Structure & $\begin{array}{l}\text { Formula } \\
(m / z)\end{array}$ & $\begin{array}{l}\text { SOA mass yields } \\
(\%)^{\mathrm{a}}\end{array}$ & & $\begin{array}{l}\text { Rate constants } \times 10^{12} \\
\left(\mathrm{~cm}^{3} \text { molec. }^{-1} \mathrm{~s}^{-1}\right)\end{array}$ \\
\hline Toluene & & $\mathrm{C}_{7} \mathrm{H}_{8}(92)$ & $\begin{array}{l}\text { 8-49 } \\
\text { (Hildebrandt et al., 2009) }\end{array}$ & $k_{\mathrm{OH}}$ & $\begin{array}{l}6.36 \\
\text { (Tully et al., 1981) }\end{array}$ \\
\hline$n$-dodecane & & $\mathrm{C}_{12} \mathrm{H}_{26}(170)$ & $\begin{array}{l}9 \\
\text { (Presto et al., 2010) }\end{array}$ & $k_{\mathrm{OH}}$ & $\begin{array}{l}13.3 \\
\text { (Lamkaddam et al., 2019) }\end{array}$ \\
\hline \multirow[t]{2}{*}{$\beta$-caryophyllene } & & \multirow[t]{2}{*}{$\mathrm{C}_{15} \mathrm{H}_{24}(205)$} & $\begin{array}{l}\text { 17-63 } \\
\text { (Griffin et al., 1999) }\end{array}$ & $k_{\mathrm{OH}}$ & $\begin{array}{l}200 \\
\text { (Shu and Atkinson, 1995) }\end{array}$ \\
\hline & & & $\begin{array}{l}53^{\mathrm{b}} \\
\text { (Jaoui et al., 2013) }\end{array}$ & $k_{\mathrm{O}_{3}}$ & $\begin{array}{l}1.16 \times 10^{-2} \\
(\text { Shu and Atkinson, 1994) }\end{array}$ \\
\hline
\end{tabular}

${ }^{\mathrm{a}}$ Measured at an organic particle concentration of $10 \mu \mathrm{g} \mathrm{m}^{-3} \cdot{ }^{\mathrm{b}}$ Measured at an organic particle concentration of $26 \mu \mathrm{g} \mathrm{m}^{-3}$.
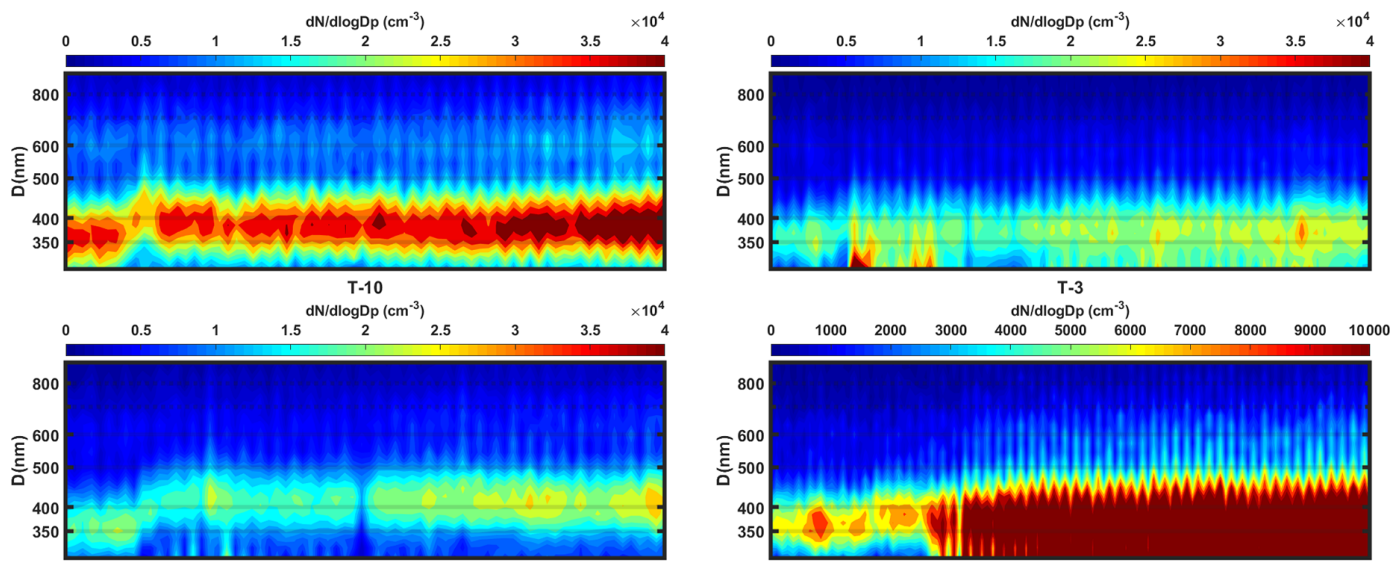

B-10

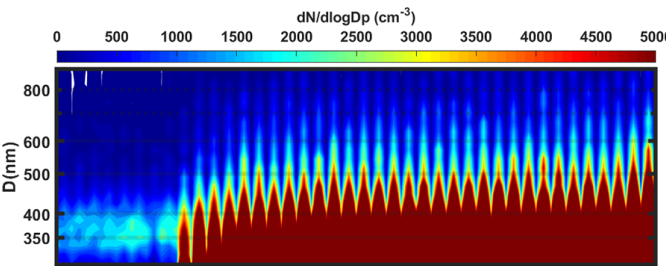

B-0
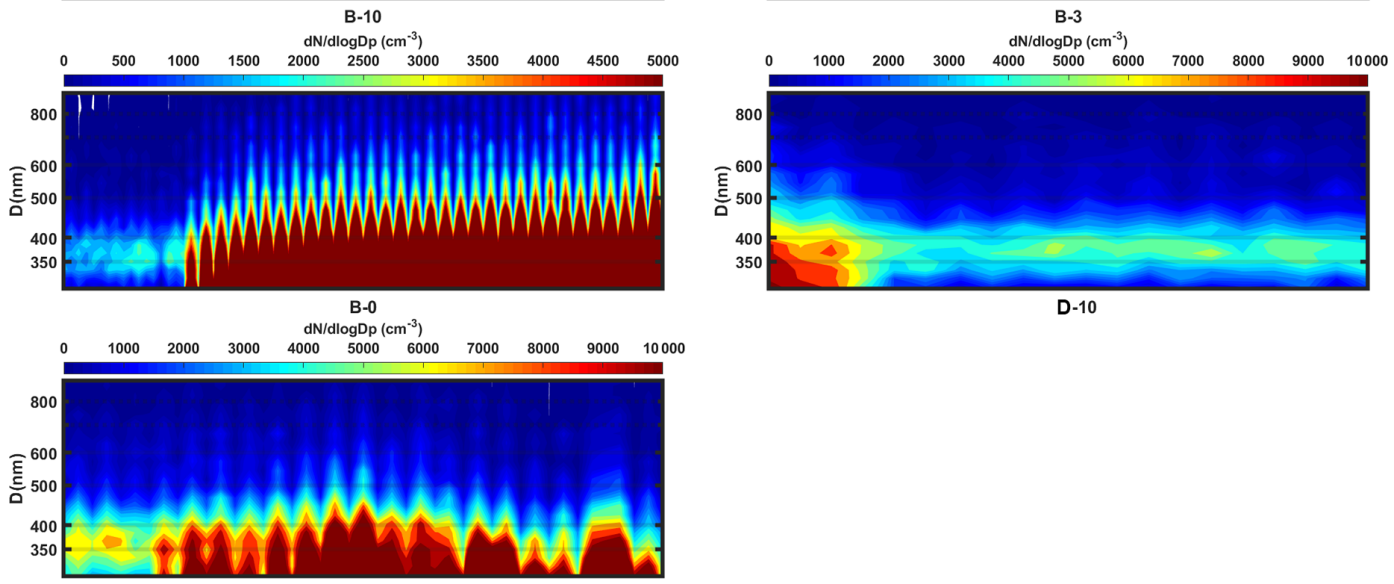

D-3

Figure B1. Temporal particle size evolution for different BC and SOA mixing experiments. The $x$ axis shows the number of scans equivalent to the experiment time. Together with the color map, the $y$ axis shows the size distribution for a certain time. A size shift from 350 to $400 \mathrm{~nm}$ can be observed for each experiment. 


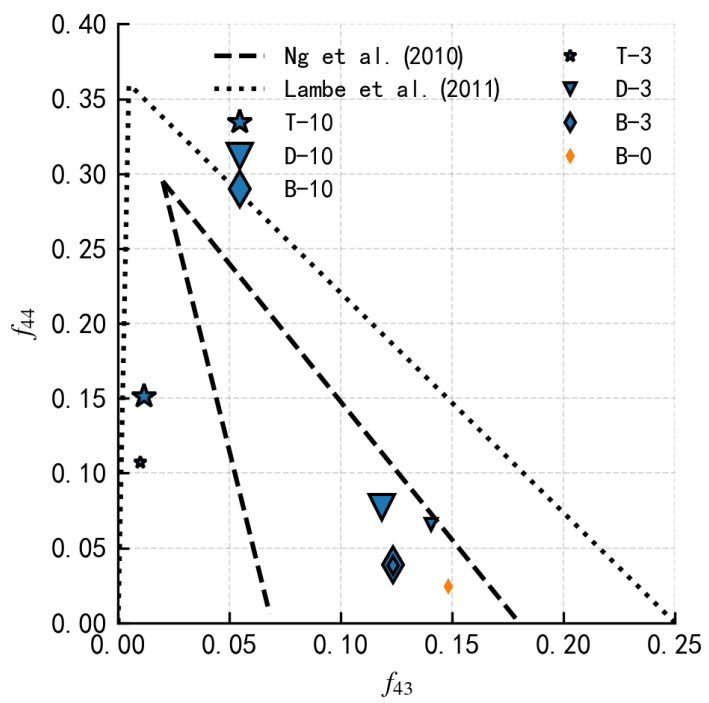

Figure B2. The measured fraction of AMS signals at $m / z=43\left(f_{43}\right)$ and $m / z=44\left(f_{44}\right)$. SOA generated from $n$-dodecane and $\beta$ caryophyllene in this study are within the ambient SOA $f_{44}$ and $f_{43}$ range measured by $\mathrm{Ng}$ et al. (2010). Toluene-derived SOA in this study exhibits a similar $f_{44}$ and $f_{43}$ signal range to the laboratory measurement of glyoxal-derived SOA (Lambe et al., 2011b). 
Data availability. Data inquires can be directed to the corresponding author (Longfei Chen; chenlongfei@ buaa.edu.cn).

Author contributions. CZ, YZ, MJW, LN, TBO, and DJC designed the experiments and methodology. $\mathrm{CZ}$ collected black carbon samples and performed morphology characterization. CZ, YZ, MJW, and CS performed the chemical analyses and measured the ice nucleation activity. CZ, YZ, MJW, LN, LC, and DJC prepared the paper with input from all coauthors.

Competing interests. The authors declare that they have no conflict of interest.

Acknowledgements. We thank our peer reviewers for their valuable comments and suggestions to make our paper scientifically improved and more concise. We thank Andrew Lambe and the other colleagues at Aerodyne Research Inc. for their help with the PAM reactor and SOA coating experiment. Longfei Chen was supported by the National Natural Science Foundation (NSF) of China (grant no. 51922019). Yue Zhang was supported by the NSF Postdoctoral Fellowship under the Atmospheric and Geospace Sciences (grant no. 1524731) and the National Institutes of Health (NIH; grant no. T32ES007018).

Financial support. This research has been supported by the Chinese Government Scholarship (grant no. 201806020052).

Review statement. This paper was edited by Hinrich Grothe and reviewed by two anonymous referees.

\section{References}

Anderson, B. E., Beyersdorf, A. J., Hudgins, C. H., Plant, J. V., Thornhill, K. L., Winstead, E. L., Ziemba, L. D., Howard, R., Corporan, E., Miake-Lye, R. C., Herndon, S. C., Timko, M., Woods, E., Dodds, W., Lee, B., Santoni, G., Whitefield, P., Hagen, D., Lobo, P., Knighton, W. B., Bulzan, D., Tacina, K., Wey, C., VanderWal, R., and Bhargava, A.: Alternative Aviation Fuel Experiment (AAFEX), National Aeronautics and Space Administration, Langley Research Center, NASA/TM-2011-217059, Hanover, 2011.

Arey, J., Winer, A. M., Atkinson, R., Aschmann, S. M., Long, W. D., Morrison, C. L., and Olszyk, D. M.: Terpenes Emitted from Agricultural Species Found in California's Central Valley, J. Geophys. Res.-Atmos., 96, 9329-9336, https://doi.org/10.1029/91JD00447, 1991.

Atkinson, R. and Arey, J.: Gas-Phase Tropospheric Chemistry of Biogenic Volatile Organic Compounds: A Review, Atmos. Environ., 37, 197-219, https://doi.org/10.1016/S13522310(03)00391-1, 2003.

Awad, O. I., Ma, X., Kamil, M., Ali, O. M., Zhang, Z., and Shuai, S.: Particulate Emissions from Gasoline Direct Injection Engines: A
Review of How Current Emission Regulations Are Being Met by Automobile Manufacturers, Sci. Total Environ., 718, 137302, https://doi.org/10.1016/j.scitotenv.2020.137302, 2020.

Bé, A. G., Upshur, M. A., Liu, P., Martin, S. T., Geiger, F. M., and Thomson, R. J.: Cloud Activation Potentials for Atmospheric $\alpha$-Pinene and $\beta$-Caryophyllene Ozonolysis Products, ACS Central Science, 3, 715-725, https://doi.org/10.1021/acscentsci.7b00112, 2017.

Berkemeier, T., Shiraiwa, M., Pöschl, U., and Koop, T.: Competition between water uptake and ice nucleation by glassy organic aerosol particles, Atmos. Chem. Phys., 14, 12513-12531, https://doi.org/10.5194/acp-14-12513-2014, 2014.

Beyersdorf, A. J., Thornhill, K. L., Winstead, E. L., Ziemba, L. D., Blake, D. R., Timko, M. T., and Anderson, B. E.: Power-Dependent Speciation of Volatile Organic Compounds in Aircraft Exhaust, Atmos. Environ., 61, 275-282, https://doi.org/10.1016/j.atmosenv.2012.07.027, 2012.

Beyersdorf, A. J., Timko, M. T., Ziemba, L. D., Bulzan, D., Corporan, E., Herndon, S. C., Howard, R., Miake-Lye, R., Thornhill, K. L., Winstead, E., Wey, C., Yu, Z., and Anderson, B. E.: Reductions in aircraft particulate emissions due to the use of Fischer-Tropsch fuels, Atmos. Chem. Phys., 14, 11-23, https://doi.org/10.5194/acp-14-11-2014, 2014.

Bhandari, J., China, S., Chandrakar, K. K., Kinney, G., Cantrell, W., Shaw, R. A., Mazzoleni, L. R., Girotto, G., Sharma, N., Gorkowski, K., Gilardoni, S., Decesari, S., Facchini, M. C., Zanca, N., Pavese, G., Esposito, F., Dubey, M. K., Aiken, A. C., Chakrabarty, R. K., Moosmüller, H., Onasch, T. B., Zaveri, R. A., Scarnato, B. V., Fialho, P., and Mazzoleni, C.: Extensive Soot Compaction by Cloud Processing from Laboratory and Field Observations, Sci. Rep.-UK, 9, 11824, https://doi.org/10.1038/s41598-019-48143-y, 2019.

Bockhorn, H., D'Anna, A., and Sarofim, A. F.: Combustion Generated Fine Carbonaceous Particles, edited by: Wang, H., Universitätsverlag Karlsruhe, Karlsruhe, 2009.

Bond, T. C., Doherty, S. J., Fahey, D. W., Forster, P. M., Berntsen, T., DeAngelo, B. J., Flanner, M. G., Ghan, S., Kärcher, B., Koch, D., Kinne, S., Kondo, Y., Quinn, P. K., Sarofim, M. C., Schultz, M. G., Schulz, M., Venkataraman, C., Zhang, H., Zhang, S., Bellouin, N., Guttikunda, S. K., Hopke, P. K., Jacobson, M. Z., Kaiser, J. W., Klimont, Z., Lohmann, U., Schwarz, J. P., Shindell, D., Storelvmo, T., Warren, S. G., and Zender, C. S.: Bounding the Role of Black Carbon in the Climate System: A Scientific Assessment, J. Geophys. Res.-Atmos., 118, 5380-5552, https://doi.org/10.1002/jgrd.50171, 2013.

Bond, T. C., Streets, D. G., Yarber, K. F., Nelson, S. M., Woo, J.-H., and Klimont, Z.: A Technology-Based Global Inventory of Black and Organic Carbon Emissions from Combustion, J. Geophys. Res.-Atmos., 109, D14203, https://doi.org/10.1029/2003jd003697, 2004.

Borgnakke, C. and Sonntag, R. E.: Thermodynamic Relations, in: Fundamentals of Thermodynamics, 8th Edn., Wiley, New York, 557-559, 2013.

Brasil, A. M., Farias, T. L., and Carvalho, M. G.: A Recipe for Image Characterization of Fractal-Like Aggregates, J. Aerosol Sci., 30, 1379-1389, https://doi.org/10.1016/S0021-8502(99)000269, 1999 .

Brooks, S. D., Suter, K., and Olivarez, L.: Effects of Chemical Aging on the Ice Nucleation Activity of Soot and Polycyclic Aro- 
matic Hydrocarbon Aerosols, J. Phys. Chem. A, 118, 1003610047, https://doi.org/10.1021/jp508809y, 2014.

Burkhardt, U. and Kärcher, B.: Global Radiative Forcing from Contrail Cirrus, Nat. Clim. Change, 1, 54, https://doi.org/10.1038/nclimate1068, 2011.

Cabot Corporation: Regal 330R Datasheet, available at: https:// www.cabotcorp.com/search/?query=regal+330R, last access: 9 October 2020.

Calogirou, A., Kotzias, D., and Kettrup, A.: Product Analysis of the Gas-Phase Reaction of $\beta$-Caryophyllene with Ozone, Atmos. Environ., 31, 283-285, https://doi.org/10.1016/13522310(96)00190-2, 1997.

Canagaratna, M. R., Jimenez, J. L., Kroll, J. H., Chen, Q., Kessler, S. H., Massoli, P., Hildebrandt Ruiz, L., Fortner, E., Williams, L. R., Wilson, K. R., Surratt, J. D., Donahue, N. M., Jayne, J. T., and Worsnop, D. R.: Elemental ratio measurements of organic compounds using aerosol mass spectrometry: characterization, improved calibration, and implications, Atmos. Chem. Phys., 15, 253-272, https://doi.org/10.5194/acp-15-253-2015, 2015.

Cape, J. N., Coyle, M., and Dumitrean, P.: The Atmospheric Lifetime of Black Carbon, Atmos. Environ., 59, 256-263, https://doi.org/10.1016/j.atmosenv.2012.05.030, 2012.

China, S., Mazzoleni, C., Gorkowski, K., Aiken, A. C., and Dubey, M. K.: Morphology and Mixing State of Individual Freshly Emitted Wildfire Carbonaceous Particles, Nat. Commun., 4, 2122, https://doi.org/10.1038/ncomms3122, 2013.

China, S., Salvadori, N., and Mazzoleni, C.: Effect of Traffic and Driving Characteristics on Morphology of Atmospheric Soot Particles at Freeway on-Ramps, Environ. Sci. Technol., 48, 3128-3135, https://doi.org/10.1021/es405178n, 2014.

China, S., Kulkarni, G., Scarnato, B. V., Sharma, N., Pekour, M., Shilling, J. E., Wilson, J., Zelenyuk, A., Chand, D., Liu, S., Aiken, A. C., Dubey, M., Laskin, A., Zaveri, R. A., and Mazzoleni, C.: Morphology of Diesel Soot Residuals from Supercooled Water Droplets and Ice Crystals: Implications for Optical Properties, Environ. Res. Lett., 10, 114010, https://doi.org/10.1088/1748-9326/10/11/114010, 2015a.

China, S., Scarnato, B., Owen, R. C., Zhang, B., Ampadu, M. T., Kumar, S., Dzepina, K., Dziobak, M. P., Fialho, P., Perlinger, J. A., Hueber, J., Helmig, D., Mazzoleni, L. R., and Mazzoleni, C.: Morphology and Mixing State of Aged Soot Particles at a Remote Marine Free Troposphere Site: Implications for Optical Properties, Geophys. Res. Lett., 42, 1243-1250, https://doi.org/10.1002/2014GL062404, 2015b.

Chou, C., Kanji, Z. A., Stetzer, O., Tritscher, T., Chirico, R., Heringa, M. F., Weingartner, E., Prévôt, A. S. H., Baltensperger, U., and Lohmann, U.: Effect of photochemical ageing on the ice nucleation properties of diesel and wood burning particles, Atmos. Chem. Phys., 13, 761-772, https://doi.org/10.5194/acp-13761-2013, 2013.

Ciccioli, P., Brancaleoni, E., Frattoni, M., Di Palo, V., Valentini, R., Tirone, G., Seufert, G., Bertin, N., Hansen, U., Csiky, O., Lenz, R., and Sharma, M.: Emission of Reactive Terpene Compounds from Orange Orchards and Their Removal by withinCanopy Processes, J. Geophys. Res.-Atmos., 104, 8077-8094, https://doi.org/10.1029/1998jd100026, 1999.

Connolly, P. J., Möhler, O., Field, P. R., Saathoff, H., Burgess, R., Choularton, T., and Gallagher, M.: Studies of heterogeneous freezing by three different desert dust samples, Atmos. Chem.
Phys., 9, 2805-2824, https://doi.org/10.5194/acp-9-2805-2009, 2009.

Crawford, I., Möhler, O., Schnaiter, M., Saathoff, H., Liu, D., McMeeking, G., Linke, C., Flynn, M., Bower, K. N., Connolly, P. J., Gallagher, M. W., and Coe, H.: Studies of propane flame soot acting as heterogeneous ice nuclei in conjunction with single particle soot photometer measurements, Atmos. Chem. Phys., 11, 9549-9561, https://doi.org/10.5194/acp-11-9549-2011, 2011.

Cziczo, D. J., Thomson, D. S., Thompson, T. L., DeMott, P. J., and Murphy, D. M.: Particle Analysis by Laser Mass Spectrometry (PALMS) Studies of Ice Nuclei and Other Low Number Density Particles, Int. J. Mass Spectrom., 258, 21-29, https://doi.org/10.1016/j.ijms.2006.05.013, 2006.

David, R. O., Fahrni, J., Marcolli, C., Mahrt, F., Brühwiler, D., and Kanji, Z. A.: The role of contact angle and pore width on pore condensation and freezing, Atmos. Chem. Phys., 20, 9419-9440, https://doi.org/10.5194/acp-20-9419-2020, 2020.

David, R. O., Marcolli, C., Fahrni, J., Qiu, Y., Perez Sirkin, Y. A., Molinero, V., Mahrt, F., Brühwiler, D., Lohmann, U., and Kanji, Z. A.: Pore Condensation and Freezing Is Responsible for Ice Formation Below Water Saturation for Porous Particles, P. Natl. Acad. Sci. USA, 116, 8184-8189, https://doi.org/10.1073/pnas.1813647116, 2019.

DeCarlo, P. F., Kimmel, J. R., Trimborn, A., Northway, M. J., Jayne, J. T., Aiken, A. C., Gonin, M., Fuhrer, K., Horvath, T., Docherty, K. S., Worsnop, D. R., and Jimenez, J. L.: Field-Deployable, High-Resolution, Time-ofFlight Aerosol Mass Spectrometer, Anal. Chem., 78, 8281-8289, https://doi.org/10.1021/ac061249n, 2006.

DeMott, P. J., Chen, Y., Kreidenweis, S. M., Rogers, D. C., and Sherman, D. E.: Ice Formation by Black Carbon Particles, Geophys. Res. Lett., 26, 2429-2432, https://doi.org/10.1029/1999GL900580, 1999.

DeMott, P. J., Cziczo, D. J., Prenni, A. J., Murphy, D. M., Kreidenweis, S. M., Thomson, D. S., Borys, R., and Rogers, D. C.: Measurements of the Concentration and Composition of Nuclei for Cirrus Formation, P. Natl. Acad. Sci. USA, 100, 14655-14660, https://doi.org/10.1073/pnas.2532677100, 2003.

DeRieux, W.-S. W., Li, Y., Lin, P., Laskin, J., Laskin, A., Bertram, A. K., Nizkorodov, S. A., and Shiraiwa, M.: Predicting the glass transition temperature and viscosity of secondary organic material using molecular composition, Atmos. Chem. Phys., 18, 6331-6351, https://doi.org/10.5194/acp-18-6331-2018, 2018.

Diehl, K. and Mitra, S. K.: A Laboratory Study of the Effects of a Kerosene-Burner Exhaust on Ice Nucleation and the Evaporation Rate of Ice Crystals, Atmos. Environ., 32, 3145-3151, https://doi.org/10.1016/S1352-2310(97)00467-6, 1998.

Ding, X., He, Q.-F., Shen, R.-Q., Yu, Q.-Q., and Wang, X.-M.: Spatial Distributions of Secondary Organic Aerosols from Isoprene, Monoterpenes, $\beta$-Caryophyllene, and Aromatics over China During Summer, J. Geophys. Res.-Atmos., 119, 1187711891, https://doi.org/10.1002/2014jd021748, 2014.

Docherty, K. S., Corse, E. W., Jaoui, M., Offenberg, J. H., Kleindienst, T. E., Krug, J. D., Riedel, T. P., and Lewandowski, M.: Trends in the Oxidation and Relative Volatility of ChamberGenerated Secondary Organic Aerosol, Aerosol Sci. Tech., 52, 992-1004, https://doi.org/10.1080/02786826.2018.1500014, 2018. 
Dooley, S., Won, S. H., Chaos, M., Heyne, J., Ju, Y., Dryer, F. L., Kumar, K., Sung, C.-J., Wang, H., Oehlschlaeger, M. A., Santoro, R. J., and Litzinger, T. A.: A Jet Fuel Surrogate Formulated by Real Fuel Properties, Combustion and Flame, 157, 23332339, https://doi.org/10.1016/j.combustflame.2010.07.001, 2010

Dooley, S., Won, S. H., Jahangirian, S., Ju, Y., Dryer, F. L., Wang, H., and Oehlschlaeger, M. A.: The Combustion Kinetics of a Synthetic Paraffinic Jet Aviation Fuel and a Fundamentally Formulated, Experimentally Validated Surrogate Fuel, Combust. Flame, 159, 3014-3020, https://doi.org/10.1016/j.combustflame.2012.04.010, 2012.

Dymarska, M., Murray, B. J., Sun, L., Eastwood, M. L., Knopf, D. A., and Bertram, A. K.: Deposition Ice Nucleation on Soot at Temperatures Relevant for the Lower Troposphere, J. Geophys. Res.-Atmos., 111, D04204, https://doi.org/10.1029/2005JD006627, 2006.

Fioletov, V. E.: Ozone Climatology, Trends, and Substances That Control Ozone, Atmos. Ocean, 46, 39-67, https://doi.org/10.3137/ao.460103, 2008.

Fisher, L. R., Gamble, R. A., and Middlehurst, J.: The Kelvin Equation and the Capillary Condensation of Water, Nature, 290, 575576, https://doi.org/10.1038/290575a0, 1981.

Fletcher, N. H.: Nucleation and Growth of Ice Crystals Upon Crystalline Substrates, Aust. J. Phys., 13, 408-418, 1960.

Fletcher, N. H.: Active Sites and Ice Crystal Nucleation, J. Atmos. Sci., 26, 1266-1271, https://doi.org/10.1175/15200469(1969)026<1266:asaicn>2.0.co;2, 1969.

Fornea, A. P., Brooks, S. D., Dooley, J. B., and Saha, A.: Heterogeneous Freezing of Ice on Atmospheric Aerosols Containing Ash, Soot, and Soil, J. Geophys. Res.-Atmos., 114, D13201, https://doi.org/10.1029/2009JD011958, 2009.

Friedman, B., Kulkarni, G., Beránek, J., Zelenyuk, A., Thornton, J. A., and Cziczo, D. J.: Ice Nucleation and Droplet Formation by Bare and Coated Soot Particles, J. Geophys. Res., 116, D17203, https://doi.org/10.1029/2011jd015999, 2011.

Frosch, M., Bilde, M., Nenes, A., Praplan, A. P., Jurányi, Z., Dommen, J., Gysel, M., Weingartner, E., and Baltensperger, $\mathrm{U}$ : $\mathrm{CCN}$ activity and volatility of $\beta$-caryophyllene secondary organic aerosol, Atmos. Chem. Phys., 13, 2283-2297, https://doi.org/10.5194/acp-13-2283-2013, 2013.

Fu, H., Zhang, M., Li, W., Chen, J., Wang, L., Quan, X., and Wang, W.: Morphology, composition and mixing state of individual carbonaceous aerosol in urban Shanghai, Atmos. Chem. Phys., 12, 693-707, https://doi.org/10.5194/acp-12-693-2012, 2012.

Garimella, S., Kristensen, T. B., Ignatius, K., Welti, A., Voigtländer, J., Kulkarni, G. R., Sagan, F., Kok, G. L., Dorsey, J., Nichman, L., Rothenberg, D. A., Rösch, M., Kirchgäßner, A. C. R., Ladkin, R., Wex, H., Wilson, T. W., Ladino, L. A., Abbatt, J. P. D., Stetzer, O., Lohmann, U., Stratmann, F., and Cziczo, D. J.: The SPectrometer for Ice Nuclei (SPIN): an instrument to investigate ice nucleation, Atmos. Meas. Tech., 9, 2781-2795, https://doi.org/10.5194/amt-9-2781-2016, 2016.

Garimella, S., Rothenberg, D. A., Wolf, M. J., David, R. O., Kanji, Z. A., Wang, C., Rösch, M., and Cziczo, D. J.: Uncertainty in counting ice nucleating particles with continuous flow diffusion chambers, Atmos. Chem. Phys., 17, 10855-10864, https://doi.org/10.5194/acp-17-10855-2017, 2017.
Gettelman, A., Hoor, P., Pan, L. L., Randel, W. J., Hegglin, M. I., and Birner, T.: The Extratropical Upper Troposphere and Lower Stratosphere, Rev. Geophys., 49, RG3003, https://doi.org/10.1029/2011RG000355, 2011.

Griffin, R. J., Cocker III, D. R., Seinfeld, J. H., and Dabdub, D.: Estimate of Global Atmospheric Organic Aerosol from Oxidation of Biogenic Hydrocarbons, Geophys. Res. Lett., 26, 2721-2724, https://doi.org/10.1029/1999g1900476, 1999.

Guenther, A. B., Jiang, X., Heald, C. L., Sakulyanontvittaya, T., Duhl, T., Emmons, L. K., and Wang, X.: The Model of Emissions of Gases and Aerosols from Nature version 2.1 (MEGAN2.1): an extended and updated framework for modeling biogenic emissions, Geosci. Model Dev., 5, 1471-1492, https://doi.org/10.5194/gmd-5-1471-2012, 2012.

Heald, C. L., Henze, D. K., Horowitz, L. W., Feddema, J., Lamarque, J. F., Guenther, A., Hess, P. G., Vitt, F., Seinfeld, J. H., Goldstein, A. H., and Fung, I.: Predicted Change in Global Secondary Organic Aerosol Concentrations in Response to Future Climate, Emissions, and Land Use Change, J. Geophys. Res.-Atmos., 113, D05211, https://doi.org/10.1029/2007JD009092, 2008.

Heald, C. L., Kroll, J. H., Jimenez, J. L., Docherty, K. S., DeCarlo, P. F., Aiken, A. C., Chen, Q., Martin, S. T., Farmer, D. K., and Artaxo, P.: A Simplified Description of the Evolution of Organic Aerosol Composition in the Atmosphere, Geophys. Res. Lett., 37, L08803, https://doi.org/10.1029/2010g1042737, 2010.

Helmig, D., Ortega, J., Guenther, A., Herrick, J. D., and Geron, C.: Sesquiterpene Emissions from Loblolly Pine and Their Potential Contribution to Biogenic Aerosol Formation in the Southeastern Us, Atmos. Environ., 40, 4150-4157, https://doi.org/10.1016/j.atmosenv.2006.02.035, 2006.

Henrot, A.-J., Stanelle, T., Schröder, S., Siegenthaler, C., Taraborrelli, D., and Schultz, M. G.: Implementation of the MEGAN (v2.1) biogenic emission model in the ECHAM6-HAMMOZ chemistry climate model, Geosci. Model Dev., 10, 903-926, https://doi.org/10.5194/gmd-10-903-2017, 2017.

Heymsfield, A. J., Krämer, M., Luebke, A., Brown, P., Cziczo, D. J., Franklin, C., Lawson, P., Lohmann, U., McFarquhar, G., Ulanowski, Z., and Van Tricht, K.: Cirrus Clouds, Meteor. Mon., 58, 2.1-2.26, https://doi.org/10.1175/amsmonographs-d16-0010.1, 2017.

Hildebrandt, L., Donahue, N. M., and Pandis, S. N.: High formation of secondary organic aerosol from the photooxidation of toluene, Atmos. Chem. Phys., 9, 2973-2986, https://doi.org/10.5194/acp-9-2973-2009, 2009.

Hildebrandt Ruiz, L., Paciga, A. L., Cerully, K. M., Nenes, A., Donahue, N. M., and Pandis, S. N.: Formation and aging of secondary organic aerosol from toluene: changes in chemical composition, volatility, and hygroscopicity, Atmos. Chem. Phys., 15, 83018313, https://doi.org/10.5194/acp-15-8301-2015, 2015.

Hinks, M. L., Montoya-Aguilera, J., Ellison, L., Lin, P., Laskin, A., Laskin, J., Shiraiwa, M., Dabdub, D., and Nizkorodov, S. A.: Effect of relative humidity on the composition of secondary organic aerosol from the oxidation of toluene, Atmos. Chem. Phys., 18, 1643-1652, https://doi.org/10.5194/acp-18-1643-2018, 2018.

Hodzic, A., Jimenez, J. L., Madronich, S., Canagaratna, M. R., DeCarlo, P. F., Kleinman, L., and Fast, J.: Modeling organic aerosols in a megacity: potential contribution of semi-volatile and intermediate volatility primary organic compounds to secondary or- 
ganic aerosol formation, Atmos. Chem. Phys., 10, 5491-5514, https://doi.org/10.5194/acp-10-5491-2010, 2010.

Hodzic, A., Kasibhatla, P. S., Jo, D. S., Cappa, C. D., Jimenez, J. L., Madronich, S., and Park, R. J.: Rethinking the global secondary organic aerosol (SOA) budget: stronger production, faster removal, shorter lifetime, Atmos. Chem. Phys., 16, 7917-7941, https://doi.org/10.5194/acp-16-7917-2016, 2016.

Hoffmann, T., Odum, J. R., Bowman, F., Collins, D., Klockow, D., Flagan, R. C., and Seinfeld, J. H.: Formation of Organic Aerosols from the Oxidation of Biogenic Hydrocarbons, J. Atmos. Chem., 26, 189-222, https://doi.org/10.1023/A:1005734301837, 1997.

Hu, D., Bian, Q., Li, T. W. Y., Lau, A. K. H., and Yu, J. Z.: Contributions of Isoprene, Monoterpenes, $\beta$-Caryophyllene, and Toluene to Secondary Organic Aerosols in Hong Kong During the Summer of 2006, J. Geophys. Res.-Atmos., 113, D22206, https://doi.org/10.1029/2008jd010437, 2008.

Huang, C.-H. and Vander Wal, R. L.: Effect of Soot Structure Evolution from Commercial Jet Engine Burning Petroleum Based Jp-8 and Synthetic Hrj and Ft Fuels, Energy \& Fuels, 27, 4946-4958, https://doi.org/10.1021/ef400576c, 2013.

IPCC: 2013: Climate Change 2013: The Physical Science Basis. Contribution of Working Group I to the Fifth Assessment Report of the Intergovernmental Panel on Climate Change, edited by: Stocker, T. F., Qin, D., Plattner, G.-K., Tignor, M., Allen, S. K., Boschung, J., Nauels, A., Xia, Y., Bex, V., and Midgley, P. M., Cambridge University Press, Cambridge, United Kingdom and New York, NY, USA, 2013.

Jacobson, M. Z.: Strong Radiative Heating Due to the Mixing State of Black Carbon in Atmospheric Aerosols, Nature, 409, 695697, https://doi.org/10.1038/35055518, 2001.

Jaoui, M., Lewandowski, M., Kleindienst, T. E., Offenberg, J. H., and Edney, E. O.: $\beta$-Caryophyllinic Acid: An Atmospheric Tracer for $\beta$-Caryophyllene Secondary Organic Aerosol, Geophys. Res. Lett., 34, L05816, https://doi.org/10.1029/2006GL028827, 2007.

Jaoui, M., Kleindienst, T. E., Docherty, K. S., Lewandowski, M., and Offenberg, J. H.: Secondary Organic Aerosol Formation from the Oxidation of a Series of Sesquiterpenes: $\alpha$ Cedrene, $\beta$-Caryophyllene, $\alpha$-Humulene and $\alpha$-Farnesene with $\mathrm{O}_{3}, \mathrm{OH}$ and $\mathrm{NO}_{3}$ Radicals, Environ. Chem., 10, 178-193, https://doi.org/10.1071/EN13025, 2013.

Johnson, J. E. and Belmont, J. A.: Modified Colored Pigments and Ink Jet Inks, Inks, and Coatings Containing Modified Colored Pigments: United States, U.S. Patent No. 5922118, 1999.

Joo, P. H., Gigone, B., Griffin, E. A., Christensen, M., and Gülder, Ö. L.: Soot Primary Particle Size Dependence on Combustion Pressure in Laminar Ethylene Diffusion Flames, Fuel, 220, 464470, https://doi.org/10.1016/j.fuel.2018.02.025, 2018.

Joyce, G. A. and Henry, W. M.: Modeling the Equilibrium Compressed Void Volume of Carbon Black, Rubber Chem. Technol., 79, 735-764, https://doi.org/10.5254/1.3547964, 2006.

Kang, E., Root, M. J., Toohey, D. W., and Brune, W. H.: Introducing the concept of Potential Aerosol Mass (PAM), Atmos. Chem. Phys., 7, 5727-5744, https://doi.org/10.5194/acp-7-5727-2007, 2007.

Kanji, Z. A. and Abbatt, J. P. D.: Laboratory Studies of Ice Formation Via Deposition Mode Nucleation onto Mineral Dust and $n$-Hexane Soot Samples, J. Geophys. Res., 111, D16204, https://doi.org/10.1029/2005jd006766, 2006.
Kanji, Z. A., DeMott, P. J., Möhler, O., and Abbatt, J. P. D.: Results from the University of Toronto continuous flow diffusion chamber at ICIS 2007: instrument intercomparison and ice onsets for different aerosol types, Atmos. Chem. Phys., 11, 31-41, https://doi.org/10.5194/acp-11-31-2011, 2011.

Kanji, Z. A., Ladino, L. A., Wex, H., Boose, Y., BurkertKohn, M., Cziczo, D. J., and Krämer, M.: Overview of Ice Nucleating Particles, Meteor. Mon., 58, 1.1-1.33, https://doi.org/10.1175/amsmonographs-d-16-0006.1, 2017.

Kärcher, B.: Formation and Radiative Forcing of Contrail Cirrus, Nat. Commun., 9, 1824, https://doi.org/10.1038/s41467018-04068-0, 2018.

Kärcher, B., Möhler, O., DeMott, P. J., Pechtl, S., and Yu, F.: Insights into the role of soot aerosols in cirrus cloud formation, Atmos. Chem. Phys., 7, 4203-4227, https://doi.org/10.5194/acp7-4203-2007, 2007.

Karlsson, M. N. A. and Martinsson, B. G.: Methods to Measure and Predict the Transfer Function Size Dependence of Individual Dmas, J. Aerosol Sci., 34, 603-625, https://doi.org/10.1016/S0021-8502(03)00020-X, 2003.

Khalizov, A. F., Zhang, R., Zhang, D., Xue, H., Pagels, J., and McMurry, P. H.: Formation of Highly Hygroscopic Soot Aerosols Upon Internal Mixing with Sulfuric Acid Vapor, J. Geophys. Res.-Atmos., 114, D05208, https://doi.org/10.1029/2008JD010595, 2009.

Kinsey, J. S., Dong, Y., Williams, D. C., and Logan, R.: Physical Characterization of the Fine Particle Emissions from Commercial Aircraft Engines During the Aircraft Particle Emissions Experiment (APEX) 1-3, Atmos. Environ., 44, 2147-2156, https://doi.org/10.1016/j.atmosenv.2010.02.010, 2010.

Kinsey, J. S., Hays, M. D., Dong, Y., Williams, D. C., and Logan, R.: Chemical Characterization of the Fine Particle Emissions from Commercial Aircraft Engines During the Aircraft Particle Emissions Experiment (APEX) 1 to 3, Environ. Sci. Technol., 45, 3415-3421, https://doi.org/10.1021/es103880d, 2011.

Kiselev, A., Bachmann, F., Pedevilla, P., Cox, S. J., Michaelides, A., Gerthsen, D., and Leisner, T.: Active Sites in Heterogeneous Ice Nucleation-the Example of K-Rich Feldspars, Science, 355, 367-371, https://doi.org/10.1126/science.aai8034, 2017.

Kittelson, D. B.: Engines and Nanoparticles: A Review, J. Aerosol Sci., 29, 575-588, https://doi.org/10.1016/S00218502(97)10037-4, 1998.

Koehler, K. A., DeMott, P. J., Kreidenweis, S. M., Popovicheva, O. B., Petters, M. D., Carrico, C. M., Kireeva, E. D., Khokhlova, T. D., and Shonija, N. K.: Cloud Condensation Nuclei and Ice Nucleation Activity of Hydrophobic and Hydrophilic Soot Particles, Phys. Chem. Chem. Phys., 11, 79067920, https://doi.org/10.1039/B905334B, 2009.

Koop, T., Luo, B., Tsias, A., and Peter, T.: Water Activity as the Determinant for Homogeneous Ice Nucleation in Aqueous Solutions, Nature, 406, 611, https://doi.org/10.1038/35020537, 2000.

Köylü, Ü. Ö., Faeth, G. M., Farias, T. L., and Carvalho, M. G.: Fractal and Projected Structure Properties of Soot Aggregates, Combustion and Flame, 100, 621-633, https://doi.org/10.1016/00102180(94)00147-K, 1995.

Kulkarni, G., China, S., Liu, S., Nandasiri, M., Sharma, N., Wilson, J., Aiken, A. C., Chand, D., Laskin, A., Mazzoleni, C., Pekour, M., Shilling, J., Shutthanandan, V., Zelenyuk, A., and Zaveri, R. A.: Ice Nucleation Activity of Diesel Soot 
Particles at Cirrus Relevant Temperature Conditions: Effects of Hydration, Secondary Organics Coating, Soot Morphology, and Coagulation, Geophys. Res. Lett., 43, 3580-3588, https://doi.org/10.1002/2016gl068707, 2016.

Kulkarni, G. R. and Kok, G. L.: Mobile Ice Nucleus Spectrometer; Pacific Northwest National Lab. (PNNL), Richland, WA (United States) PNNL-21384, 600306000 United States 10.2172/1071991, 600306000 PNNL English, Medium: ED, Size: PDFN, 2012.

Lambe, A. T., Ahern, A. T., Williams, L. R., Slowik, J. G., Wong, J. P. S., Abbatt, J. P. D., Brune, W. H., Ng, N. L., Wright, J. P., Croasdale, D. R., Worsnop, D. R., Davidovits, P., and Onasch, T. B.: Characterization of aerosol photooxidation flow reactors: heterogeneous oxidation, secondary organic aerosol formation and cloud condensation nuclei activity measurements, Atmos. Meas. Tech., 4, 445-461, https://doi.org/10.5194/amt-4445-2011, 2011a

Lambe, A. T., Onasch, T. B., Massoli, P., Croasdale, D. R., Wright, J. P., Ahern, A. T., Williams, L. R., Worsnop, D. R., Brune, W. H., and Davidovits, P.: Laboratory studies of the chemical composition and cloud condensation nuclei (CCN) activity of secondary organic aerosol (SOA) and oxidized primary organic aerosol (OPOA), Atmos. Chem. Phys., 11, 8913-8928, https://doi.org/10.5194/acp-11-8913-2011, 2011b.

Lamkaddam, H., Gratien, A., Ropion, M., Pangui, E., and Doussin, J.-F.: Kinetic Study of the Temperature Dependence of OhInitiated Oxidation of N-Dodecane, J. Phys. Chem. A, 123, 9462-9468, https://doi.org/10.1021/acs.jpca.9b07704, 2019.

Lapuerta, M., Martos, F. J., and Herreros, J. M.: Effect of Engine Operating Conditions on the Size of Primary Particles Composing Diesel Soot Agglomerates, J. Aerosol Sci., 38, 455-466, https://doi.org/10.1016/j.jaerosci.2007.02.001, 2007.

Lee, A., Goldstein, A. H., Kroll, J. H., Ng, N. L., Varutbangkul, V., Flagan, R. C., and Seinfeld, J. H.: Gas-Phase Products and Secondary Aerosol Yields from the Photooxidation of 16 Different Terpenes, J. Geophys. Res.-Atmos., 111, D17305, https://doi.org/10.1029/2006jd007050, 2006

Lee, C. and Kramer, T. A.: Prediction of Three-Dimensional Fractal Dimensions Using the Two-Dimensional Properties of Fractal Aggregates, Adv. Colloid Interfac., 112, 49-57, https://doi.org/10.1016/j.cis.2004.07.001, 2004.

Lee, D. S., Fahey, D. W., Forster, P. M., Newton, P. J., Wit, R. C. N., Lim, L. L., Owen, B., and Sausen, R.: Aviation and Global Climate Change in the 21st Century, Atmos. Environ., 43, 35203537, https://doi.org/10.1016/j.atmosenv.2009.04.024, 2009.

Lee, D. S., Pitari, G., Grewe, V., Gierens, K., Penner, J. E., Petzold, A., Prather, M. J., Schumann, U., Bais, A., Berntsen, T., Iachetti, D., Lim, L. L., and Sausen, R.: Transport Impacts on Atmosphere and Climate: Aviation, Atmos. Environ., 44, 46784734, https://doi.org/10.1016/j.atmosenv.2009.06.005, 2010.

Lee-Taylor, J., Madronich, S., Aumont, B., Baker, A., Camredon, M., Hodzic, A., Tyndall, G. S., Apel, E., and Zaveri, R. A.: Explicit modeling of organic chemistry and secondary organic aerosol partitioning for Mexico City and its outflow plume, Atmos. Chem. Phys., 11, 13219-13241, https://doi.org/10.5194/acp-11-13219-2011, 2011.

Lefebvre, A. H.: Gas Turbine Combustion, CRC press, Boca Raton, FL, USA, 1998.
Li, K., Chen, L., Han, K., Lv, B., Bao, K., Wu, X., Gao, X., and Cen, K.: Smog Chamber Study on Aging of Combustion Soot in Isoprene/ $/ \mathrm{SO}_{2} / \mathrm{NO}_{x}$ System: Changes of Mass, Size, Effective Density, Morphology and Mixing State, Atmos. Res., 184, 139148, https://doi.org/10.1016/j.atmosres.2016.10.011, 2017.

Li, K., Liggio, J., Lee, P., Han, C., Liu, Q., and Li, S.-M.: Secondary organic aerosol formation from $\alpha$-pinene, alkanes, and oil-sands-related precursors in a new oxidation flow reactor, Atmos. Chem. Phys., 19, 9715-9731, https://doi.org/10.5194/acp19-9715-2019, 2019.

Li, M., Karu, E., Brenninkmeijer, C., Fischer, H., Lelieveld, J., and Williams, J.: Tropospheric $\mathrm{OH}$ and Stratospheric $\mathrm{OH}$ and $\mathrm{Cl}$ Concentrations Determined from $\mathrm{CH}_{4}, \mathrm{CH}_{3} \mathrm{Cl}$, and $\mathrm{SF}_{6}$ Measurements, Climate and Atmospheric Science, 1, 29, https://doi.org/10.1038/s41612-018-0041-9, 2018.

Li, W., Shao, L., Zhang, D., Ro, C.-U., Hu, M., Bi, X., Geng, H., Matsuki, A., Niu, H., and Chen, J.: A Review of Single Aerosol Particle Studies in the Atmosphere of East Asia: Morphology, Mixing State, Source, and Heterogeneous Reactions, J. Clean. Prod., 112, 1330-1349, https://doi.org/10.1016/j.jclepro.2015.04.050, 2016.

Li, Y., Day, D. A., Stark, H., Jimenez, J. L., and Shiraiwa, M.: Predictions of the glass transition temperature and viscosity of organic aerosols from volatility distributions, Atmos. Chem. Phys., 20, 8103-8122, https://doi.org/10.5194/acp-208103-2020, 2020.

Liati, A., Brem, B. T., Durdina, L., Vogtli, M., Dasilva, Y. A., Eggenschwiler, P. D., and Wang, J.: Electron Microscopic Study of Soot Particulate Matter Emissions from Aircraft Turbine Engines, Environ. Sci. Technol., 48, 10975-10983, https://doi.org/10.1021/es501809b, 2014.

Liati, A., Schreiber, D., Dimopoulos Eggenschwiler, P., Arroyo Rojas Dasilva, Y., and Spiteri, A. C.: Electron Microscopic Characterization of Soot Particulate Matter Emitted by Modern Direct Injection Gasoline Engines, Combust. Flame, 166, 307-315, https://doi.org/10.1016/j.combustflame.2016.01.031, 2016.

Liu, T., Huang, D. D., Li, Z., Liu, Q., Chan, M., and Chan, C. $\mathrm{K}$.: Comparison of secondary organic aerosol formation from toluene on initially wet and dry ammonium sulfate particles at moderate relative humidity, Atmos. Chem. Phys., 18, 56775689, https://doi.org/10.5194/acp-18-5677-2018, 2018.

Lobo, P., Durdina, L., Smallwood, G. J., Rindlisbacher, T., Siegerist, F., Black, E. A., Yu, Z., Mensah, A. A., Hagen, D. E., Miake-Lye, R. C., Thomson, K. A., Brem, B. T., Corbin, J. C., Abegglen, M., Sierau, B., Whitefield, P. D., and Wang, J.: Measurement of Aircraft Engine Non-Volatile Pm Emissions: Results of the Aviation-Particle Regulatory Instrumentation Demonstration Experiment (A-PRIDE) 4 Campaign, Aerosol Sci. Tech., 49, 472484, https://doi.org/10.1080/02786826.2015.1047012, 2015.

Loza, C. L., Craven, J. S., Yee, L. D., Coggon, M. M., Schwantes, R. H., Shiraiwa, M., Zhang, X., Schilling, K. A., Ng, N. L., Canagaratna, M. R., Ziemann, P. J., Flagan, R. C., and Seinfeld, J. H.: Secondary organic aerosol yields of 12-carbon alkanes, Atmos. Chem. Phys., 14, 1423-1439, https://doi.org/10.5194/acp14-1423-2014, 2014.

Lund, M. T., Samset, B. H., Skeie, R. B., Watson-Parris, D., Katich, J. M., Schwarz, J. P., and Weinzierl, B.: Short Black Carbon Lifetime Inferred from a Global Set of Air- 
craft Observations, Climate and Atmospheric Science, 1, 31, https://doi.org/10.1038/s41612-018-0040-x, 2018.

Lüönd, F., Stetzer, O., Welti, A., and Lohmann, U.: Experimental Study on the Ice Nucleation Ability of Size-Selected Kaolinite Particles in the Immersion Mode, J. Geophys. Res.-Atmos., 115, D14201, https://doi.org/10.1029/2009jd012959, 2010.

Mahrt, F., Kilchhofer, K., Marcolli, C., Grönquist, P., David, R. O., Rösch, M., Lohmann, U., and Kanji, Z. A.: The Impact of Cloud Processing on the Ice Nucleation Abilities of Soot Particles at Cirrus Temperatures, J. Geophys. Res.-Atmos., 125, e2019JD030922, https://doi.org/10.1029/2019jd030922, 2020.

Mahrt, F., Marcolli, C., David, R. O., Grönquist, P., Barthazy Meier, E. J., Lohmann, U., and Kanji, Z. A.: Ice nucleation abilities of soot particles determined with the Horizontal Ice Nucleation Chamber, Atmos. Chem. Phys., 18, 13363-13392, https://doi.org/10.5194/acp-18-13363-2018, 2018.

Mandelbrot, B. B.: The Fractal Geometry of Nature, W. H. Freeman and Company, San Francisco, 1982.

Marcolli, C.: Deposition nucleation viewed as homogeneous or immersion freezing in pores and cavities, Atmos. Chem. Phys., 14, 2071-2104, https://doi.org/10.5194/acp-14-2071-2014, 2014.

Mason, R. H., Si, M., Chou, C., Irish, V. E., Dickie, R., Elizondo, P., Wong, R., Brintnell, M., Elsasser, M., Lassar, W. M., Pierce, K. M., Leaitch, W. R., MacDonald, A. M., Platt, A., ToomSauntry, D., Sarda-Estève, R., Schiller, C. L., Suski, K. J., Hill, T. C. J., Abbatt, J. P. D., Huffman, J. A., DeMott, P. J., and Bertram, A. K.: Size-resolved measurements of ice-nucleating particles at six locations in North America and one in Europe, Atmos. Chem. Phys., 16, 1637-1651, https://doi.org/10.5194/acp16-1637-2016, 2016.

Moffet, R. C., O’Brien, R. E., Alpert, P. A., Kelly, S. T., Pham, D. Q., Gilles, M. K., Knopf, D. A., and Laskin, A.: Morphology and mixing of black carbon particles collected in central California during the CARES field study, Atmos. Chem. Phys., 16, 1451514525, https://doi.org/10.5194/acp-16-14515-2016, 2016.

Möhler, O., Büttner, S., Linke, C., Schnaiter, M., Saathoff, H., Stetzer, O., Wagner, R., Krämer, M., Mangold, A., Ebert, V., and Schurath, U.: Effect of Sulfuric Acid Coating on Heterogeneous Ice Nucleation by Soot Aerosol Particles, J. Geophys. Res.Atmos., 110, D11210, https://doi.org/10.1029/2004JD005169, 2005a.

Möhler, O., Linke, C., Saathoff, H., Schnaiter, M., Wagner, R., Mangold, A., Krämer, M., and Schurath, U.: Ice Nucleation on Flame Soot Aerosol of Different Organic Carbon Content, Meteorol. Z., 14, 477-484, https://doi.org/10.1127/0941-2948/2005/0055, 2005 b.

Moore, R. H., Thornhill, K. L., Weinzierl, B., Sauer, D., D'Ascoli, E., Kim, J., Lichtenstern, M., Scheibe, M., Beaton, B., Beyersdorf, A. J., Barrick, J., Bulzan, D., Corr, C. A., Crosbie, E., Jurkat, T., Martin, R., Riddick, D., Shook, M., Slover, G., Voigt, C., White, R., Winstead, E., Yasky, R., Ziemba, L. D., Brown, A., Schlager, H., and Anderson, B. E.: Biofuel Blending Reduces Particle Emissions from Aircraft Engines at Cruise Conditions, Nature, 543, 411-415, https://doi.org/10.1038/nature21420, 2017.

Murphy, D. M., Thomson, D. S., Middlebrook, A. M., and Schein, M. E.: In Situ Single-Particle Characterization at Cape Grim, J. Geophys. Res.-Atmos., 103, 16485-16491, https://doi.org/10.1029/97JD03281, 1998.
Murray, B. J., Wilson, T. W., Dobbie, S., Cui, Z., Al-Jumur, S. M. R. K., Möhler, O., Schnaiter, M., Wagner, R., Benz, S., Niemand, M., Saathoff, H., Ebert, V., Wagner, S., and Kärcher, B.: Heterogeneous Nucleation of Ice Particles on Glassy Aerosols under Cirrus Conditions, Nat. Geosci., 3, 233-237, https://doi.org/10.1038/ngeo817, 2010.

Ng, N. L., Canagaratna, M. R., Zhang, Q., Jimenez, J. L., Tian, J., Ulbrich, I. M., Kroll, J. H., Docherty, K. S., Chhabra, P. S., Bahreini, R., Murphy, S. M., Seinfeld, J. H., Hildebrandt, L., Donahue, N. M., DeCarlo, P. F., Lanz, V. A., Prévôt, A. S. H., Dinar, E., Rudich, Y., and Worsnop, D. R.: Organic aerosol components observed in Northern Hemispheric datasets from Aerosol Mass Spectrometry, Atmos. Chem. Phys., 10, 46254641, https://doi.org/10.5194/acp-10-4625-2010, 2010.

Ng, N. L., Canagaratna, M. R., Jimenez, J. L., Chhabra, P. S., Seinfeld, J. H., and Worsnop, D. R.: Changes in organic aerosol composition with aging inferred from aerosol mass spectra, Atmos. Chem. Phys., 11, 6465-6474, https://doi.org/10.5194/acp11-6465-2011, 2011.

Nguyen, T. L., Winterhalter, R., Moortgat, G., Kanawati, B., Peeters, J., and Vereecken, L.: The Gas-Phase Ozonolysis of $\beta$-Caryophyllene $\left(\mathrm{C}_{15} \mathrm{H}_{24}\right)$. Part Ii: A Theoretical Study, Phys. Chem. Chem. Phys., 11, 4173-4183, https://doi.org/10.1039/B817913A, 2009.

Nichman, L., Wolf, M., Davidovits, P., Onasch, T. B., Zhang, Y., Worsnop, D. R., Bhandari, J., Mazzoleni, C., and Cziczo, D. J.: Laboratory study of the heterogeneous ice nucleation on blackcarbon-containing aerosol, Atmos. Chem. Phys., 19, 1217512194, https://doi.org/10.5194/acp-19-12175-2019, 2019

Oh, C. and Sorensen, C. M.: The Effect of Overlap between Monomers on the Determination of Fractal Cluster Morphology, J. Colloid Interfac., 193, 17-25, https://doi.org/10.1006/jcis.1997.5046, 1997.

Onasch, T. B., Jayne, J. T., Herndon, S., Worsnop, D. R., MiakeLye, R. C., Mortimer, I. P., and Anderson, B. E.: Chemical Properties of Aircraft Engine Particulate Exhaust Emissions, J. Propul. Power, 25, 1121-1137, https://doi.org/10.2514/1.36371, 2009.

Onasch, T. B., Trimborn, A., Fortner, E. C., Jayne, J. T., Kok, G. L., Williams, L. R., Davidovits, P., and Worsnop, D. R.: Soot Particle Aerosol Mass Spectrometer: Development, Validation, and Initial Application, Aerosol Sci. Tech., 46, 804-817, https://doi.org/10.1080/02786826.2012.663948, 2012.

Pandis, S. N., Harley, R. A., Cass, G. R., and Seinfeld, J. H.: Secondary Organic Aerosol Formation and Transport, Atmos. Environ. A-Gen., 26, 2269-2282, https://doi.org/10.1016/09601686(92)90358-R, 1992.

Pereira, K. L., Rovelli, G., Song, Y. C., Mayhew, A. W., Reid, J. P., and Hamilton, J. F.: A new aerosol flow reactor to study secondary organic aerosol, Atmos. Meas. Tech., 12, 4519-4541, https://doi.org/10.5194/amt-12-4519-2019, 2019.

Persiantseva, N. M., Popovicheva, O. B., and Shonija, N. K.: Wetting and Hydration of Insoluble Soot Particles in the Upper Troposphere, J. Environ. Monitor., 6, 939-945, https://doi.org/10.1039/B407770A, 2004.

Petzold, A., Ström, J., Ohlsson, S., and Schröder, F. P.: Elemental Composition and Morphology of Ice-Crystal Residual Particles in Cirrus Clouds and Contrails, Atmos. Res., 49, 21-34, https://doi.org/10.1016/S0169-8095(97)00083-5, 1998. 
Pison, I. and Menut, L.: Quantification of the Impact of Aircraft Traffic Emissions on Tropospheric Ozone over Paris Area, Atmos. Environ., 38, 971-983, https://doi.org/10.1016/j.atmosenv.2003.10.056, 2004.

Popovicheva, O. B., Persiantseva, N. M., Lukhovitskaya, E. E., Shonija, N. K., Zubareva, N. A., Demirdjian, B., Ferry, D., and Suzanne, J.: Aircraft Engine Soot as Contrail Nuclei, Geophys. Res. Lett., 31, L11104, https://doi.org/10.1029/2003GL018888, 2004.

Presto, A. A., Miracolo, M. A., Donahue, N. M., and Robinson, A. L.: Secondary Organic Aerosol Formation from High- $\mathrm{NO}_{x}$ Photo-Oxidation of Low Volatility Precursors: N-Alkanes, Environ. Sci. Technol., 44, 2029-2034, https://doi.org/10.1021/es903712r, 2010.

Pruppacher, H. R. and Klett, J. D.: Microphysics of Clouds and Precipitation, 2nd Edn., Atmospheric and Oceanographic Sciences Library, 18, Springer Netherlands, XXII, 954 pp., 2010.

Pusechel, R. F., Blake, D. F., Snetsinger, K. G., Hansen, A. D. A., Verma, S., and Kato, K.: Black Carbon (Soot) Aerosol in the Lower Stratosphere and Upper Troposphere, Geophys. Res. Lett., 19, 1659-1662, https://doi.org/10.1029/92GL01801, 1992.

Ramachandran, G. and Reist, P. C.: Characterization of Morphological Changes in Agglomerates Subject to Condensation and Evaporation Using Multiple Fractal Dimensions, Aerosol Sci. Tech., 23, 431-442, https://doi.org/10.1080/02786829508965326, 1995.

Raza, M., Chen, L., Leach, F., and Ding, S.: A Review of Particulate Number (PN) Emissions from Gasoline Direct Injection (GDI) Engines and Their Control Techniques, Energies, 11, 1417, https://doi.org/10.3390/en11061417, 2018.

Sakulyanontvittaya, T., Duhl, T., Wiedinmyer, C., Helmig, D., Matsunaga, S., Potosnak, M., Milford, J., and Guenther, A.: Monoterpene and Sesquiterpene Emission Estimates for the United States, Environ. Sci. Technol., 42, 1623-1629, https://doi.org/10.1021/es702274e, 2008.

Samson, R. J., Mulholland, G. W., and Gentry, J. W.: Structural Analysis of Soot Agglomerates, Langmuir, 3, 272-281, https://doi.org/10.1021/la00074a022, 1987.

Schilling, K. A., Yee, L. D., Loza, C. L., Coggon, M. M., Schwantes, R., Zhang, X., Dalleska, N. F., and Seinfeld, J. H.: Secondary Organic Aerosol Composition from $\mathrm{C}_{12}$ Alkanes, J. Phys. Chem. A, 119, 4281-4297, https://doi.org/10.1021/jp501779w, 2015.

Seinfeld, J. H.: Clouds, Contrails and Climate, Nature, 391, 837838, 1998.

Shu, Y. and Atkinson, R.: Rate Constants for the GasPhase Reactions of $\mathrm{O}_{3}$ with a Series of Terpenes and $\mathrm{OH}$ Radical Formation from the $\mathrm{O}_{3}$ Reactions with Sesquiterpenes at 296 $\pm 2 \mathrm{~K}$, Int. J. Chem. Kinet., 26, 1193-1205, https://doi.org/10.1002/kin.550261207, 1994.

Shu, Y. and Atkinson, R.: Atmospheric Lifetimes and Fates of a Series of Sesquiterpenes, J. Geophys. Res.-Atmos., 100, 72757281, https://doi.org/10.1029/95JD00368, 1995.

Simonen, P., Saukko, E., Karjalainen, P., Timonen, H., Bloss, M., Aakko-Saksa, P., Rönkkö, T., Keskinen, J., and Dal Maso, M.: A new oxidation flow reactor for measuring secondary aerosol formation of rapidly changing emission sources, Atmos. Meas. Tech., 10, 1519-1537, https://doi.org/10.5194/amt10-1519-2017, 2017.
Slowik, J. G., Cross, E. S., Han, J.-H., Kolucki, J., Davidovits, P., Williams, L. R., Onasch, T. B., Jayne, J. T., Kolb, C. E., and Worsnop, D. R.: Measurements of Morphology Changes of Fractal Soot Particles Using Coating and Denuding Experiments: Implications for Optical Absorption and Atmospheric Lifetime, Aerosol Sci. Tech., 41, 734-750, https://doi.org/10.1080/02786820701432632, 2007.

Smekens, A., Godoi, R. H. M., Berghmans, P., and Van Grieken, R.: Characterisation of Soot Emitted by Domestic Heating, Aircraft and Cars Using Diesel or Biodiesel, J. Atmos. Chem., 52, 45-62, https://doi.org/10.1007/s10874-005-6903-7, 2005.

Steane, A. M.: Phase Change, in: Thermodynamics: A Complete Undergraduate Course, Oxford University Press, 2016.

Timko, M. T., Albo, S. E., Onasch, T. B., Fortner, E. C., Yu, Z., Miake-Lye, R. C., Canagaratna, M. R., Ng, N. L., and Worsnop, D. R.: Composition and Sources of the Organic Particle Emissions from Aircraft Engines, Aerosol Sci. Tech., 48, 61-73, https://doi.org/10.1080/02786826.2013.857758, 2014

Tritscher, T., Jurányi, Z., Martin, M., Chirico, R., Gysel, M. Heringa, M. F., DeCarlo, P. F., Sierau, B., Prévôt, A. S. H., Weingartner, E., and Baltensperger, U.: Changes of Hygroscopicity and Morphology During Ageing of Diesel Soot, Environ. Res. Lett., 6, 034026, https://doi.org/10.1088/1748-9326/6/3/034026, 2011.

Tsigaridis, K. and Kanakidou, M.: Global modelling of secondary organic aerosol in the troposphere: a sensitivity analysis, Atmos. Chem. Phys., 3, 1849-1869, https://doi.org/10.5194/acp-3-18492003, 2003.

Tsimpidi, A. P., Karydis, V. A., Zavala, M., Lei, W., Molina, L., Ulbrich, I. M., Jimenez, J. L., and Pandis, S. N.: Evaluation of the volatility basis-set approach for the simulation of organic aerosol formation in the Mexico City metropolitan area, Atmos. Chem. Phys., 10, 525-546, https://doi.org/10.5194/acp-10-5252010, 2010.

Tully, F. P., Ravishankara, A. R., Thompson, R. L., Nicovich, J. M., Shah, R. C., Kreutter, N. M., and Wine, P. H.: Kinetics of the Reactions of Hydroxyl Radical with Benzene and Toluene, J. Phys. Chem., 85, 2262-2269, https://doi.org/10.1021/j150615a025, 1981.

Vali, G., DeMott, P. J., Möhler, O., and Whale, T. F.: Technical Note: A proposal for ice nucleation terminology, Atmos. Chem. Phys., 15, 10263-10270, https://doi.org/10.5194/acp-15-102632015, 2015.

Vander Wal, R. L., Bryg, V. M., and Huang, C.-H.: Aircraft Engine Particulate Matter: Macro- Micro- and Nanostructure by Hrtem and Chemistry by Xps, Combustion and Flame, 161, 602-611, https://doi.org/10.1016/j.combustflame.2013.09.003, 2014.

Volkamer, R., Platt, U., and Wirtz, K.: Primary and Secondary Glyoxal Formation from Aromatics: Experimental Evidence for the Bicycloalkyl-Radical Pathway from Benzene, Toluene, and P-Xylene, J. Phys. Chem. A, 105, 7865-7874, https://doi.org/10.1021/jp010152w, 2001.

Wang, Y., Liu, H., and Lee, C.-F. F.: Particulate Matter Emission Characteristics of Diesel Engines with Biodiesel or Biodiesel Blending: A Review, Renew. Sustain. Energ. Rev., 64, 569-581, https://doi.org/10.1016/j.rser.2016.06.062, 2016.

Wang, Y., Liu, F., He, C., Bi, L., Cheng, T., Wang, Z., Zhang, H., Zhang, X., Shi, Z., and Li, W.: Fractal Dimensions and Mixing Structures of Soot Particles During At- 
mospheric Processing, Environ. Sci. Tech. Let., 4, 487-493, https://doi.org/10.1021/acs.estlett.7b00418, 2017.

Welti, A., Lüönd, F., Stetzer, O., and Lohmann, U.: Influence of particle size on the ice nucleating ability of mineral dusts, Atmos. Chem. Phys., 9, 6705-6715, https://doi.org/10.5194/acp-9-67052009, 2009.

Wey, C., Anderson, B., Hudgins, C., Wey, C., Li-Jones, X., Winstead, E., Thornhill, L., Lobo, P., Hagen, D., and Whitefield, P.: Aircraft Particle Emissions Experiment (APEX), NASA, Hanover, MD, USA, 2006.

Winterhalter, R., Herrmann, F., Kanawati, B., Nguyen, T. L., Peeters, J., Vereecken, L., and Moortgat, G. K.: The GasPhase Ozonolysis of $\beta$-Caryophyllene $\left(\mathrm{C}_{15} \mathrm{H}_{24}\right)$. Part I: An Experimental Study, Phys. Chem. Chem. Phys., 11, 4152-4172, https://doi.org/10.1039/B817824K, 2009.

Wolf, M. J., Coe, A., Dove, L. A., Zawadowicz, M. A., Dooley, K., Biller, S. J., Zhang, Y., Chisholm, S. W., and Cziczo, D. J.: Investigating the Heterogeneous Ice Nucleation of Sea Spray Aerosols Using Prochlorococcus as a Model Source of Marine Organic Matter, Environ. Sci. Technol., 53, 1139-1149, https://doi.org/10.1021/acs.est.8b05150, 2019.

Yee, L. D., Craven, J. S., Loza, C. L., Schilling, K. A., Ng, N. L., Canagaratna, M. R., Ziemann, P. J., Flagan, R. C., and Seinfeld, J. H.: Effect of chemical structure on secondary organic aerosol formation from C12 alkanes, Atmos. Chem. Phys., 13, 1112111140, https://doi.org/10.5194/acp-13-11121-2013, 2013.

Yu, P., Toon, O. B., Bardeen, C. G., Zhu, Y., Rosenlof, K. H., Portmann, R. W., Thornberry, T. D., Gao, R.-S., Davis, S. M., Wolf, E. T., de Gouw, J., Peterson, D. A., Fromm, M. D., and Robock, A.: Black Carbon Lofts Wildfire Smoke High into the Stratosphere to Form a Persistent Plume, Science, 365, 587-590, https://doi.org/10.1126/science.aax1748, 2019.

Zawadowicz, M. A., Abdelmonem, A., Mohr, C., Saathoff, H., Froyd, K. D., Murphy, D. M., Leisner, T., and Cziczo, D. J.: Single-Particle Time-of-Flight Mass Spectrometry Utilizing a Femtosecond Desorption and Ionization Laser, Anal. Chem., 87, 12221-12229, https://doi.org/10.1021/acs.analchem.5b03158, 2015.

Zhang, C., Hui, X., Lin, Y., and Sung, C.-J.: Recent Development in Studies of Alternative Jet Fuel Combustion: Progress, Challenges, and Opportunities, Renew. Sust. Energ. Rev., 54, 120138, https://doi.org/10.1016/j.rser.2015.09.056, 2016.

Zhang, R., Khalizov, A. F., Pagels, J., Zhang, D., Xue, H., and McMurry, P. H.: Variability in Morphology, Hygroscopicity, and Optical Properties of Soot Aerosols During Atmospheric Processing, P. Natl. Acad. Sci. USA, 105, 10291-10296, https://doi.org/10.1073/pnas.0804860105, 2008.

Zhang, X., Chen, X., and Wang, J.: A Number-Based Inventory of Size-Resolved Black Carbon Particle Emissions by Global Civil Aviation, Nat. Commun., 10, 534, https://doi.org/10.1038/s41467-019-08491-9, 2019.

Zhang, Y., Sanchez, M. S., Douet, C., Wang, Y., Bateman, A. P., Gong, Z., Kuwata, M., Renbaum-Wolff, L., Sato, B. B., Liu, P. F., Bertram, A. K., Geiger, F. M., and Martin, S. T.: Changing shapes and implied viscosities of suspended submicron particles, Atmos. Chem. Phys., 15, 7819-7829, https://doi.org/10.5194/acp15-7819-2015, 2015.
Zhang, Y., Chen, Y., Lambe, A. T., Olson, N. E., Lei, Z., Craig, R. L., Zhang, Z., Gold, A., Onasch, T. B., Jayne, J. T., Worsnop, D. R., Gaston, C. J., Thornton, J. A., Vizuete, W., Ault, A. P., and Surratt, J. D.: Effect of the Aerosol-Phase State on Secondary Organic Aerosol Formation from the Reactive Uptake of IsopreneDerived Epoxydiols (IEPOX), Environ. Sci. Tech. Let., 5, 167174, https://doi.org/10.1021/acs.estlett.8b00044, 2018 a.

Zhang, Y., Favez, O., Canonaco, F., Liu, D., Močnik, G., Amodeo, T., Sciare, J., Prévôt, A. S. H., Gros, V., and Albinet, A.: Evidence of Major Secondary Organic Aerosol Contribution to Lensing Effect Black Carbon Absorption Enhancement, Climate and Atmospheric Science, 1, 47, https://doi.org/10.1038/s41612018-0056-2, 2018b.

Zhang, Y., Katira, S., Lee, A., Lambe, A. T., Onasch, T. B., Xu, W., Brooks, W. A., Canagaratna, M. R., Freedman, A., Jayne, J. T., Worsnop, D. R., Davidovits, P., Chandler, D., and Kolb, C. E.: Kinetically controlled glass transition measurement of organic aerosol thin films using broadband dielectric spectroscopy, Atmos. Meas. Tech., 11, 3479-3490, https://doi.org/10.5194/amt11-3479-2018, 2018c.

Zhang, Y., Liu, F., Clavel, D., Smallwood, G. J., and Lou, C.: Measurement of Soot Volume Fraction and Primary Particle Diameter in Oxygen Enriched Ethylene Diffusion Flames Using the Laser-Induced Incandescence Technique, Energy, 177, 421-432, https://doi.org/10.1016/j.energy.2019.04.062, 2019a.

Zhang, Y., Nichman, L., Spencer, P., Jung, J. I., Lee, A., Heffernan, B. K., Gold, A., Zhang, Z., Chen, Y., Canagaratna, M. R., Jayne, J. T., Worsnop, D. R., Onasch, T. B., Surratt, J. D., Chandler, D., Davidovits, P., and Kolb, C. E.: The Cooling Rate- and VolatilityDependent Glass-Forming Properties of Organic Aerosols Measured by Broadband Dielectric Spectroscopy, Environ. Sci. Technol., 53, 12366-12378, https://doi.org/10.1021/acs.est.9b03317, 2019 b.

Zhao, D. F., Buchholz, A., Kortner, B., Schlag, P., Rubach, F., Fuchs, H., Kiendler-Scharr, A., Tillmann, R., Wahner, A., Watne, Å. K., Hallquist, M., Flores, J. M., Rudich, Y., Kristensen, K., Hansen, A. M. K., Glasius, M., Kourtchev, I., Kalberer, M., and Mentel, Th. F.: Cloud condensation nuclei activity, droplet growth kinetics, and hygroscopicity of biogenic and anthropogenic secondary organic aerosol (SOA), Atmos. Chem. Phys., 16, 1105-1121, https://doi.org/10.5194/acp16-1105-2016, 2016.

Zhao, L., Yang, T., Kaiser, R. I., Troy, T. P., Ahmed, M., Ribeiro, J. M., Belisario-Lara, D., and Mebel, A. M.: Combined Experimental and Computational Study on the Unimolecular Decomposition of JP-8 Jet Fuel Surrogates. Ii: nDodecane $\left(n-\mathrm{C}_{12} \mathrm{H}_{26}\right)$, J. Phys. Chem. A, 121, 1281-1297, https://doi.org/10.1021/acs.jpca.6b11817, 2017. 